\title{
Coverage and quality of DNA barcode references for Central and Northern European Odonata
}

\author{
Matthias Geiger ${ }^{\text {Corresp., } 1}$, Stephan Koblmüller ${ }^{2}$, Giacomo Assandri ${ }^{3}$, Andreas Chovanec ${ }^{4,5}$, Torbjørn Ekrem ${ }^{6}$, Iris \\ Fischer $^{5,7,8}$, Andrea Galimberti ${ }^{9}$, Michał Grabowski ${ }^{10}$, Elisabeth Haring ${ }^{5,7,8}$, Axel Hausmann ${ }^{11}$, Lars Hendrich ${ }^{11}$, \\ Stefan Koch ${ }^{12}$, Tomasz Mamos $^{10}{ }^{10}$ Udo Rothe ${ }^{13}$, Björn Rulik ${ }^{1}$, Tomasz Rewicz ${ }^{10}$, Marcia Sittenthaler ${ }^{7}$, Elisabeth \\ Stur $^{6}$, Grzegorz Tończyk ${ }^{10}$, Lukas Zangl ${ }^{2,14,15}$, Jerome Moriniere ${ }^{16}$ \\ ${ }^{1}$ Zoologisches Forschungsmuseum Alexander Koenig (ZFMK) - Leibniz Institute for Animal Biodiversity, Bonn, Germany \\ 2 Institute of Biology, University of Graz, Graz, Steiermark, Austria \\ 3 Area per l'Avifauna Migratrice, Istituto Superiore per la Protezione e la Ricerca Ambientale (ISPRA), Ozzano Emilia, BO, Italy \\ 4 Federal Ministry of Agriculture, Regions and Tourism, Vienna, Austria \\ 5 Department of Functional and Evolutionary Ecology, University of Vienna, Vienna, Austria \\ 6 Department of Natural History, NTNU University Museum, Norwegian University of Science and Technology, Trondheim, Trøndelag, Norway \\ 7 Central Research Laboratories, Natural History Museum Vienna, Vienna, Austria \\ 8 Department of Evolutionary Biology, University of Vienna, Vienna, Austria \\ 9 Department of Biotechnology and Biosciences, ZooPlantLab, University of Milano - Bicocca, Milano, Italy \\ 10 Department of Invertebrate Zoology and Hydrobiology, University of Lodz, Łódź, Poland \\ 11 SNSB-Zoologische Staatssammlung, München, BY, Germany \\ 12 Independent Researcher, Mindelheim, Germany \\ 13 Naturkundemuseum Potsdam, Potsdam, BB, Germany \\ 14 ÖKOTEAM - Institute for Animal Ecology and Landscape Planning, Graz, Steiermark, Austria \\ 15 Universalmuseum Joanneum, Studienzentrum Naturkunde, Graz, Steiermark, Austria \\ 16 AIM - Advanced Identification Methods GmbH, Leipzig, SN, Germany \\ Corresponding Author: Matthias Geiger \\ Email address: m.geiger@leibniz-zfmk.de
}

Background. Dragonflies and damselflies (Odonata) are important components in biomonitoring due to their amphibiotic lifecycle and specific habitat requirements. They are charismatic and popular insects, but can be challenging to identify despite large size and often distinct coloration, especially the immature stages. DNA-based assessment tools rely on validated DNA barcode reference libraries evaluated in a supraregional context to minimize taxonomic incongruence and identification mismatches.

Methods. This study reports on findings from the analysis of the most comprehensive DNA barcode dataset for Central European Odonata to date, with 103 out of 145 recorded European species included and publicly deposited in the Barcode of Life Data System (BOLD). The complete dataset includes 697 specimens (548 adults, 108 larvae) from 274 localities in 16 countries with a geographic emphasis on Central Europe. We used BOLD to generate sequence divergence metrics and to examine the taxonomic composition of the DNA barcode clusters within the dataset and in comparison with all data on BOLD.

Results. Over $88 \%$ of the species included can be readily identified using their DNA barcodes and the reference dataset provided. Considering the complete European dataset, unambiguous identification is hampered in 12 species due to weak mitochondrial differentiation and partial haplotype sharing. However, considering the known species distributions only two groups of five species possibly co-occur, 
leading to an unambiguous identification of more than $95 \%$ of the analysed Odonata via DNA barcoding in real applications. The cases of small interspecific genetic distances and the observed deep intraspecific variation in Cordulia aenea (Linnaeus, 1758) are discussed in detail and the corresponding taxa in the public reference database highlighted. They should be considered in future applications of DNA barcoding and metabarcoding and represent interesting evolutionary biological questions, which call for in depth analyses of the involved taxa throughout their distribution ranges. 


\section{Coverage and quality of DNA barcode references for 2 Central and Northern European Odonata}

3

4

5

Matthias Geiger ${ }^{1}$, Stephan Koblmüller ${ }^{2}$, Giacomo Assandri ${ }^{3}$, Andreas Chovanec ${ }^{4,5}$, Torbjørn Ekrem $^{6}$, Iris Fischer ${ }^{4,7,8}$, Andrea Galimberti ${ }^{9}$, Michał Grabowski ${ }^{10}$, Elisabeth Haring ${ }^{7,8}$, Axel Hausmann ${ }^{11}$, Lars Hendrich ${ }^{11}$, Stefan Koch ${ }^{12}$, Tomasz Mamos ${ }^{10}$, Udo Rothe ${ }^{13}$, Björn Rulik ${ }^{1}$, Tomasz Rewicz $^{10}$, Marcia Sittenthaler ${ }^{7}$, Elisabeth Stur ${ }^{6}$, Grzegorz Tończyk ${ }^{10}$, Lukas Zang1 ${ }^{2,14,15}$, Jérôme Morinière ${ }^{16}$

${ }^{1}$ Zoologisches Forschungsmuseum Alexander Koenig (ZFMK), Leibniz Institute for Animal Biodiversity, Bonn, NRW, Germany ${ }^{2}$ Institute of Biology, University of Graz, Graz, Steiermark, Austria

${ }^{3}$ Area per l'Avifauna Migratrice, Istituto Superiore per la Protezione e la Ricerca Ambientale (ISPRA), Ozzano Emilia, BO, Italy.

${ }^{4}$ Department of Functional and Evolutionary Ecology, University of Vienna, Vienna, Austria

${ }^{5}$ Federal Ministry of Agriculture, Regions and Tourism, Vienna, Austria

${ }^{6}$ Department of Natural History, NTNU University Museum, Norwegian University of Science and Technology, Trondheim, Trøndelag, Norway

${ }^{7}$ Central Research Laboratories, Natural History Museum Vienna, Vienna, Austria

${ }^{8}$ Department of Evolutionary Biology, University of Vienna, Vienna, Austria

${ }^{9}$ Department of Biotechnology and Biosciences, ZooPlantLab, University of Milano - Bicocca, Milano, Italy

${ }^{10}$ Department of Invertebrate Zoology and Hydrobiology, University of Lodz, Łódź, Poland

${ }^{11}$ SNSB-Zoologische Staatssammlung, München, BY, Germany

${ }^{12}$ Katzenhirn 1, Mindelheim, Germany

${ }^{13}$ Naturkundemuseum Potsdam, Potsdam, BB, Germany

${ }^{14}$ ÖKOTEAM - Institute for Animal Ecology and Landscape Planning, Graz, Steiermark, Austria

${ }^{15}$ Universalmuseum Joanneum, Studienzentrum Naturkunde, Graz, Steiermark, Austria

${ }^{16}$ AIM - Advanced Identification Methods GmbH, Leipzig, SN, Germany

Corresponding Author:

Matthias F. Geiger ${ }^{1}$

Adenauerallee 130, Bonn, NRW, 53113, Germany

Email address: m.geiger@leibniz-zfmk.de

\section{Abstract}


39 Background. Dragonflies and damselflies (Odonata) are important components in biomonitoring 40 due to their amphibiotic lifecycle and specific habitat requirements. They are charismatic and 41 popular insects, but can be challenging to identify despite large size and often distinct coloration, 42 especially the immature stages. DNA-based assessment tools rely on validated DNA barcode 43 reference libraries evaluated in a supraregional context to minimize taxonomic incongruence and 44 identification mismatches.

45 Methods. This study reports on findings from the analysis of the most comprehensive DNA 46 barcode dataset for Central European Odonata to date, with 103 out of 145 recorded European 47 species included and publicly deposited in the Barcode of Life Data System (BOLD). The 48 complete dataset includes 697 specimens (548 adults, 108 larvae) from 274 localities in 16 49 50 countries with a geographic emphasis on Central Europe. We used BOLD to generate sequence divergence metrics and to examine the taxonomic composition of the DNA barcode clusters within the dataset and in comparison with all data on BOLD.

Results. Over $88 \%$ of the species included can be readily identified using their DNA barcodes and the reference dataset provided. Considering the complete European dataset, unambiguous identification is hampered in 12 species due to weak mitochondrial differentiation and partial haplotype sharing. However, considering the known species distributions only two groups of five species possibly co-occur, leading to an unambiguous identification of more than $95 \%$ of the analysed Odonata via DNA barcoding in real applications. The cases of small interspecific genetic distances and the observed deep intraspecific variation in Cordulia aenea (Linnaeus, 1758) are discussed in detail and the corresponding taxa in the public reference database highlighted. They should be considered in future applications of DNA barcoding and metabarcoding and represent interesting evolutionary biological questions, which call for in depth analyses of the involved taxa throughout their distribution ranges.

\section{Introduction}

Dragonflies (Anisoptera) and damselflies (Zygoptera) of the order Odonata constitute a nearly cosmopolitan group of insects of about 7,000 species (Kalkman et al., 2008). The group is recorded from all continents except Antarctica and has its highest levels of diversity in the tropics (Kalkman et al., 2008). Their relatively large size, striking morphology, sometimes bright coloration and interesting biology make them popular among nature lovers (Garrison, von Ellenrieder \& Louton 2006). Due to the comparatively small number of species occurring in Europe $(<150$, see Kalkman et al., 2010), their life history strategies, ecological requirements and distribution are relatively well-studied. Odonata is therefore also one of the few insect taxa comprehensively covered in national and international Red List assessments. The most recent European Red List considers about $15 \%$ of the 138 assessed species as threatened (Kalkman et al., 2010). The most important threats to odonates are desiccation of their habitats due to global warming, and intensified water uptake for consumption and agriculture (Kalkman et al., 2010). 
78 Dragonflies and damselflies are also routinely used for assessment and monitoring of ecological

79 status within the European Water Framework Directive (WFD, Directive 2000/60/EC; European

80 Commission, 2000). For instance, a dragonfly association index was developed for Austria in

81 order to assess the ecological status of rivers within the system of the Water Framework

82 Directive and to evaluate restoration measures (Chovanec \& Waringer, 2015). Despite our wide

83 knowledge of odonates, some species and especially their larvae and exuviae - which are crucial

84 for judging autochthony - cannot be readily and easily identified in the field. This is among the

85 reasons why comparatively few species are used in regular WFD assessments. In Germany, for

86 instance, less than a quarter of the occurring species are used (Haase, Sundermann \&

87 Schindehütte, 2006).

88 DNA-based methods for species identification known as DNA barcoding and DNA

89 metabarcoding allow more comprehensive assessments of aquatic communities (Hajibabaei et

90 al., 2011; Taberlet et al., 2012; Elbrecht et al., 2017; Leese et al., 2016; 2018). It has been also

91 demonstrated that non-invasive approaches relying on DNA and cells from filtered water

92 samples can be effective in detecting relevant taxa (e.g., Hajibabaei et al., 2012; Majaneva et al.,

93 2018; Zizka et al., 2019). Crucial for accurate and effective metabarcoding of environmental- or

94 bulk sample DNA is a comprehensive and high quality database of reference DNA barcodes,

95 built on correctly identified, well-documented and vouchered specimens (Weigand et al., 2019).

96 A recent analysis on the availability of reference data for DNA-based assessment of European

97 aquatic taxa showed that dragonfly species are among the best covered insect taxa (Weigand et

98 al., 2019). Yet, of the 1206 DNA barcodes Weigand et al. (2019) analyzed only 251 representing

9949 species were then public and could be quality-checked. Ten percent of the species with DNA

100 barcodes were represented by one specimen only and $6 \%$ of the species were missing from the

101 DNA barcode reference library completely (June $\left.12^{\text {th }}, 2019\right)$. When the more reliable threshold

102 of five DNA barcodes per species was assessed, the proportion of available sequences dropped to

103 ca. $60 \%$ of the species with less than $20 \%$ of them being publicly available. The remaining

104 sequences and associated metadata were at the time private in the Barcode of Life Data Systems

105 (BOLD, www.boldsystems.org; Ratnasingham \& Hebert, 2007) and could therefore not be

106 evaluated. Regional representation is shown to be important for accurate identification using

107 DNA Barcoding (e.g., Bergsten et al., 2012). A wider geographic coverage was lacking for many

108 odonate species when Weigand et al. (2019) assessed the order (e.g. no public data from Italy,

109 only 12 species from Germany, 13 from Poland, 2 from Norway, etc.), thereby increasing the

110 probability of underestimating molecular diversity (e.g., from refugial areas; Galimberti et al.,

111 2020) and also hampering routine DNA-based assessments by lacking reliable reference

112 barcodes. The latest significant additions to the reference library for European Odonata in BOLD

113 were those from Malta and Italy (Rewicz et al., 2020; Galimberti et al., 2020). The latter

114 publication presented the first comprehensive DNA barcode library for Italian odonates and

115 examined diversity and distribution of mitochondrial lineages on the Holarctic scale.

116 The present study brings together results from different European DNA barcoding initiatives,

117 compiles the available data for joint evaluation, and presents new data to facilitate DNA-based 
118 monitoring approaches of aquatic ecosystems. Feeding high quality data into public repositories 119 such as BOLD is not trivial since thorough evaluation of the data before publication is needed to 120 avoid and reduce noise stemming from mis- or un-identified specimens (Trebitz et al., 2015; 121 Rulik et al., 2017; Collins \& Cruickshank, 2013; Becker, Hanner \& Steinke, 2011). Iterative

122

123

124

125

126

127

128

129

130

131

132

133

134

135

136

137

138

139

140

141

142

143

144

145

146

147

148

149

150

151

152

153

154

155

156

157 processes for the validation of generated DNA barcode data should ideally incorporate both new and published data. The process of assembling near-complete reference libraries for species-rich taxa bears the chance to also identify taxonomic inconsistencies during the process, and the possibility to discuss and correct them before deposition of premature taxonomic hypotheses. Often, those issues can only be addressed through comparisons of material collected throughout a species' distribution range, including material of closely related species. Such data also makes it possible to investigate if DNA barcoding accuracy is influenced by spatial effects as documented for beetles (Bergsten et al., 2012), moths (Hausmann et al., 2013) and fish (Geiger et al., 2014).

The "BIN Discordance" analysis in BOLD is a tool for the validation of newly generated data that helps to reveal two different cases of potential taxonomic inconsistencies: a) specimens assigned to different species that share a molecular operational taxonomic unit (termed BIN barcode index number), or b) specimens of a particular species are assigned to two or more BINs. For the majority of studied insect orders, a BIN very often represents a close speciesproxy as delineated by traditional taxonomy (e.g., for Lepidoptera, Hausmann et al., 2013). However, some genera or families throughout all taxa exhibit problems with simple species delineation based on DNA barcodes. This is often due to high intra- or low inter-specific genetic distances (see Hubert \& Hanner, 2015). Every "disagreement/conflict" case is then the starting point for re-evaluation of both DNA sequences and morphological data. We follow the concept of Integrative Taxonomy (Padial et al., 2010; Schlick-Steiner et al., 2010; Fujita et al., 2012) to infer whether there are potential, previously overlooked species in our data. This is a widely recognized phenomenon when analysing comprehensive DNA barcode datasets and can impact not only macroecology and conservation issues but also reveal fascinating research objects pointing at evolutionary mechanisms of cryptic speciation (Struck \& Cerca, 2020).

Several such cases have been published where DNA sequences have helped revealing hidden species level diversity in odonates (Mitchell \& Samways, 2005; Damm et al., 2010; LópezEstrada et al., 2020; Vega-Sanchez et al., 2020). Neglecting the presence of cryptic diversity does not only lead to underestimation of factual biodiversity, but also can impair indicator species approaches as different taxa react differently to stressors (Zettler et al., 2013; Macher et al., 2016). But also the opposite - low or absent mitochondrial divergence between species - is expected to occur in large DNA barcode datasets. While this can prevent ready delineation of species with one mitochondrial marker only, it is important to document these cases as starting points for further in-depth studies or revisions (e.g., "warnings" as in Galimberti et al., 2020).

In this publication we analyze available and newly generated DNA barcodes for European damselflies and dragonflies to i) evaluate quality of the new data through comparisons with 
158

159

160

161

162

163

164

165

166

167

168

169

170

171

172

173

174

175

176

177

178

179

180

181

182

183

184

185

186

187

188

189

190

191

192

193

194

195

196

197

available DNA barcodes in BOLD, ii) reveal cases of shared BINs between species indicative for the need of more thorough studies, and iii) detect potential cases of cryptic diversity, i.e. when the same morphological species is assigned to two or more BINs.

\section{Materials \& Methods}

Acronyms used: CCDB - Canadian Center for DNA Barcoding; DNAqua-Net - EU COST Action CA15219 on "Developing new genetic tools for bioassessment of aquatic ecosystems in Europe"; GBOL - German Barcode of Life initiative; KFUG - Karl-Franzens-Universität Graz; NHMW - Naturhistorisches Museum Wien (Natural History Museum Vienna); SNSB-ZSM Staatliche Naturwissenschaftliche Sammlungen Bayerns, Zoologische Staatssammlung München; NTNU - Norwegian University of Science and Technology; ZFMK - Zoologisches Forschungsmuseum Alexander Koenig, Leibniz Institute for Animal Biodiversity.

A network of over 30 institutional taxonomists and external specialists collected and contributed specimens to the different DNA barcoding campaigns, in number of specimens primarily from Germany (SNSB-ZSM, ZFMK), Poland (University of Lodz), Italy (University of MilanoBicocca, private collection G. Assandri) and Norway (through the NTNU University Museum and Norwegian Barcode of Life Network, NorBOL). Additional specimens were contributed from Austria (NHMW, University of Graz) and Romania (Babes-Bolyai University).

Field permits: For samples from Germany field work permits were issued by the responsible state environmental offices in Bavaria [Bayerisches Staatsministerium für Umwelt und Gesundheit, for the project: "Barcoding Fauna Bavarica"] and from the Amt für Natur- und Landschaftsschutz, Rhein-Sieg-Kreis (67.1-1.03-19/2016KRO). Italian specimens were collected in part in protected areas and some of the collected species are included in the EU Habitats Directive. The Italian Ministry of the Environment, Land and Sea released a national permit for the collection of species included in European and Italian conservation directives or to collect samples in regional or national protected areas (Prot. $\mathrm{n}^{\circ}$ 0031783.20-11-2019). Austrian specimens were collected with permits from the provincial governments of Burgenland (A4/NN.AB-10097-5-2017 and A4/NN.AB-10200-5-2019), Lower Austria (RU5-BE-1489/001208; RU5-BE-64/018-2018), Styria (ABT13-53S-7/1996-156 and ABT13-53W-50/2018-2) and Vienna (MA22-169437/2017). Polish specimens from Wigierski National Park were collected under the permit no. 12/2018 issued by the Park authorities to Grzegorz Tończyk. All the other material did not require additional permits for legal collection. None of the collected specimens from Norway were from areas where sampling is restricted. Thus, sample permits were not required.

Most studied specimens were adults (see below) of which the majority were stored in $>96 \%$ EtOH prior to DNA extraction. The remaining samples were derived from dry-preserved material. Specimen ages at the time of sequencing ranged from $0-4$ years (79\%) to up to 16 years 
198 (21\%). For subsequent analyses we aimed to select only DNA barcode sequences $>500 \mathrm{bp}$,

199

200

201

202

203

204

205

206

207

208

209

210

211

212

213

214

215

216

217

218

219

220

221

222

223

224

225

226

227

228

229

230

231

232

233

234

235

236 maximum taxonomic coverage and to fill gaps in the catalogue of Central European Odonata through combined evaluation of DNA barcodes we included 39 partial DNA barcodes shorter than 500 bp and 9 sequences publicly available in BOLD ( 8 mined from GenBank). The number of specimens available per species ranged from 1 (15 singletons) to 49 in Ischnura elegans (Vander Linden, 1820) (mean=6.8; $\mathrm{SD}=7.4)$. For problematic taxa, i.e. species that shared BINs or species that were assigned to more than one BIN and whose patterns could not be explained by our data, we downloaded additional DNA barcode sequences available on BOLD with the hope that data covering a larger geographic distribution will allow us to elucidate the process underlying BIN sharing or deep intraspecific divergence. Detailed information on collection sites and dates is available in Supplementary file S1. Voucher information such as life stage, locality data, habitat, altitude, collector, identifier, taxonomic classifications, habitus images, DNA barcode sequences, primer pairs, and trace files are publicly accessible in the "DS-ODOGER DNA barcode references for Central and Northern European Odonata" dataset in BOLD (http://www.boldsystems.org -DOI: dx.doi.org/10.5883/DS-ODOGER). The respective voucher specimens are deposited in public and private collections listed in Supplementary file S1.

Laboratory protocols. Protocols for generating DNA barcodes varied between laboratories and projects due to either being organism specific or taxonomically broadly oriented.

For samples analysed at the CCDB, submitted by SNSB-ZSM, NorBOL, DNAqua-Net from Poland: A tissue sample was removed from each specimen and transferred into 96 well plates for subsequent DNA extraction, PCR and bi-directional Sanger sequencing at CCDB. All protocols for DNA extraction, PCR amplifications, and Sanger sequencing procedures are available online under: (ccdb.ca/resources/). Samples were first amplified with a cocktail of standard and modified Folmer PCR primers CLepFolF (5' - ATT CAA CCA ATC ATA AAG ATA TTG G) and CLepFolR (5' - TAA ACT TCT GGA TGT CCA AAA AAT CA) targeting the full DNA barcode fragment (see Hernández-Triana et al., 2014). The same primers were employed for subsequent bidirectional Sanger sequencing reactions (see also Ivanova et al., 2006). A second PCR round was conducted for a selection of samples that did not amplify in the first attempt and targeted the mini-barcode (313 bp) proposed by Leray et al. (2013) with primers dgHCO2198 and mlCOIintF.

The samples submitted to CCDB through DNAqua-Net from Poland were amplified with the primers OdoF1_t1 (5' - TGT AAA ACG ACG GCC AGT ATT CAA CHA ATC ATA ARG ATA TTG G) and OdoR1_t1 (5' - CAG GAA ACA GCT ATG ACT AAA CTT CTG GAT GYC CRA ARA AYC A) and subsequently sequenced with M13 primers.

ZFMK: Tissue sub-sampling, DNA extraction, polymerase chain reaction (in house at ZFMK) and sequencing (BGI Genomics) followed standard protocols (Astrin et al., 2016) and are described in detail in Rulik et al. (2017).

PeerJ reviewing PDF | (2020:08:52354:1:1:NEW 11 Feb 2021) 
237 KFUG: DNA extraction followed a rapid Chelex protocol described in Richlen \& Barber (2005),

238

239

240

241

242

243

244

245

246

247

248

249

250

251

252

253

254

255

256

257

258

259

260

261

262

263

264

265

266

267

268

269

270

271

272

273

274

275

subsequent PCR, clean-up and bidirectional Sanger sequencing were performed following Duftner, Koblmüller \& Sturmbauer (2005) and Koblmüller et al. (2011) using the primers ODO_LCO1490d (5' - TTT CTA CWA ACC AYA AAG ATA TTG G) and ODO_HCO2198d (5' - TAA ACT TCW GGR TGT CCA AAR AAT CA) (Dijkstra et al., 2014).

NHMW: DNA extraction was performed with the DNeasy Blood and Tissue Kit (Qiagen) using the standard protocol specified by the company. For PCR amplification two primer sets were used (Haring et al., 2020): the complete sequence of the cytochrome c oxidase subunit 1 gene (COI) plus partial sections of the flanking tRNA genes were amplified with the primers TyrOdo-F (5' - CTC CTA TAT AGA TTT ACA GTC T - 3') and Leu-Odo-R (5' - CTT AAA TCC ATT GCA CTT TTC TGC C - 3') resulting in amplicon lengths of $\sim 1660$ bp $\left(54{ }^{\circ} \mathrm{C}\right.$ annealing temperature). Alternatively, primers CO1-Odo-F5 (5' - TGC GAC RA TGR CTG TTT TC - 3') and CO1-Odo-R6 (5' - TGC ACT TTT CTG CCA CAT TAA A - 3') were combined to amplify almost the complete COI gene (amplicon length $1532 \mathrm{bp}, 47^{\circ} \mathrm{C}$ annealing temperature). PCR was performed in a volume of $50 \mu$ l containing $0.5 \mu$ l Qiagen Taq polymerase ( 5 units $/ \mu 1), 5 \mu 1$ $10 \times$ PCR Buffer, $10 \mu$ Q Q-Solution (Qiagen), $1.5 \mathrm{mM} \mathrm{MgCl2,2.5} \mathrm{mM} \mathrm{dNTP} \mathrm{Mix,} 0.5 \mu \mathrm{M}$ of each primer, and $1 \mu \mathrm{LNA}$ template. The PCR cycling protocol included an initial denaturation at $94{ }^{\circ} \mathrm{C}$ for $3 \mathrm{~min}$, followed by 35 cycles of denaturation at $94{ }^{\circ} \mathrm{C}$ for $1 \mathrm{~min}$, annealing for $30 \mathrm{~s}$, extension at $72{ }^{\circ} \mathrm{C}$ for $30 \mathrm{~s}$. The final step was an extension at $72{ }^{\circ} \mathrm{C}$ for $10 \mathrm{~min}$. Samples were sequenced bidirectionally using the PCR and two internal primers (CO1-Odo-F3 5'- GAT TCT TTG GAC AYC CHG AAG -3' and CO1-Odo-R3 5'- GTT TCC TTT TTA CCT CTT TCT TG $\left.3^{\prime}\right)$.

Methods for generating DNA barcodes from additional material from Poland (Lodz) follows Rewicz et al. (2020); the procedures for Italian specimens are described in Galimberti et al. (2020). An overview of the primer combinations used and references thereof are given in the Supplementary file S4.

Data analysis. Sequence divergences for the COI-5P barcode region (mean and maximum intraspecific variation and minimum genetic distance to the nearest-neighbor species) were calculated using the "Distance Summary" and "Barcode Gap Analysis" tools in BOLD, employing the Kimura-2-Parameter (K2P) distance metric (Puillandre et al., 2012) after aligning all sequences $>500$ bp length with the amino acid HMM based algorithm and pairwise deletion of positions with missing data. BOLD's BIN Discordance analysis was applied to detect either BINs containing different species, or species split into two or more BINs. BOLD groups all DNA barcodes (public and non-public) into clusters of highly similar sequences, which are then assigned unique BIN identifier (Ratnasingham \& Hebert, 2013). It enables identification of specimens also when taxonomic information is widely lacking (e.g., Moriniere et al. 2017). As the BIN system is dynamic and dependent on the underlying data, the composition of a BIN can change over time. The analyses in this study were conducted on May18th in 2020.

Peer) reviewing PDF | (2020:08:52354:1:1:NEW 11 Feb 2021) 
276 The mitochondrial relationships based on the DNA barcode region were visualized via 277 Maximum Likelihood (ML) trees inferred in IQ-TREE (Nguyen et al., 2015) using the 278 PhyloSuite platform (Zhang et al., 2020). Analyses were done separately for Anisoptera and 279 Zygoptera for enhanced presentability and due to presumably different rates of molecular 280 evolution (e. g., Koroiva \& Kvist, 2018). Best fitting models of evolution were inferred based on 281 the Bayesian Information Criterion (BIC) in ModelFinder (Kalyaanamoorthy et al., 2017). These 282 models - GTR+F+R5 and GTR+F+R3 for the Anisoptera and Zygoptera datasets, respectively, 283 were then applied for ML tree searches with 10000 ultrafast bootstrap replicates conducted in

284

285

286

287

288

289

290

291

292

293

294

295

296

297

298

299

300

301

302

303

304

305

306

307

308

309

310

311

312

313

314

315 IQ-TREE. Separate ML trees were inferred in IQ-TREE for representative examples for i) taxa that shared BINs (Anax spp. with model HKY+F+I) or ii) showed deep intraspecific divergence (Cordulia aenea with model TIM2+F+G4). For cases of deep intraspecific divergence, additional sequences of closely related taxa not present in our initial dataset were downloaded from BOLD and included in the analysis.

\section{Results}

Reference library \& dataset description. Success in DNA barcode creation ranged from 58\% (SNSB and ZFMK - standard protocols at CCDB and in GBOL) to 100\% (Austrian and Italian specimens - Odonata-tailored protocols). The complete dataset (online in BOLD as DSODOGER) contained 697 specimens belonging to 103 species bearing a binomen with a COI sequence length range of 309-692 (mean $631 \mathrm{SD}=73.9)$ bp. Of those, only $3(0.43 \%)$ have not been assigned a BIN due to insufficient length $(<500 \mathrm{bp})$ and some ambiguities. Thirty-nine records $(5.6 \%)$ were included with a partial DNA barcode only $(<500 \mathrm{bp})$, most of them (35) resulting from the $2^{\text {nd }}$ PCR approach with the Leray et al. (2013) mini-barcode primer pair of SNSB-ZSM. Out of all entries analysed, 663 (95.28\%) are documented in BOLD with GPS coordinates for 274 localities (partly approximated due to conservation issues), 656 (94.25\%) contain information on life stage (548 adults, 108 larvae). The final dataset had a geographic emphasis on Central Europe (Figure 1) and contained specimens from Germany (288), Poland (159), Italy (100), Norway (92) and Austria (28). The remaining specimens were collected in Bulgaria (1), France (5), Greece (3), Hungary (2), Montenegro (4), Morocco (5), Netherlands (1), Romania (5), Russia (1), Spain (1) and Sweden (2).

Data evaluation. The internal BIN discordance report (using BOLD v4 on May 18, 2020) evaluated the resulting 96 BINs with 694 individuals and revealed the presence of conflicting taxonomic assignments in 7 BINs encompassing 183 individuals (Table 1). The remaining 74 BINs (plus 15 singleton BINs) did not contain conflicting taxonomic assignments (496 individuals). Of the 103 taxa assigned to a Linnean binomen based on morphological identification, $86.40 \%$ ( $74+15$ singletons) are unambiguously discriminated by their DNA barcodes at a European scale. 
316 Extending the BIN discordance evaluation to all other data in the reference library (using BOLD 317 v3) revealed a higher proportion of conflicting signal in the global database: 31 of the 96 BINs 318 (358 records) contained records of mixed taxonomic annotations (6 on genus and 25 on species 319 level). While the 6 genus level conflicts were most likely due to coarse misidentification, sample 320 mix-up in a laboratory, sample number mix-up of specimens in BOLD or nomenclatural changes

321

322

323

324

325

326

327

328

329

330

331

332

333

334

335

336

337

338

339

340

341

342

343

344

345

346

347

348

349

350

351

352

353

354

not applied to all affected datasets in BOLD (e.g., Lestes Leach, 1815 and Chalcolestes

Kennedy, 1920), the remaining 25 BINs with mixed species annotations contained 18 cases listed in Table 2 (in addition to the 7 BINs listed in Table 1).

Of the 103 taxa assigned a Linnean binomen based on morphological identification, at least $77.66 \%$ (65 + 15 singletons) are unambiguously discriminated by their DNA barcodes $(83.49 \%$ when neglecting the genus level discordance).

Of the $25 \mathrm{BINs}$ with mixed species annotations, 14 species contained more than 3 specimens in our dataset and could be tested for the presence of diagnostic nucleotide positions allowing for an unambiguous species assignment with a character-based delineation approach. Five of these 14 species possess at least 1 diagnostic position and are all well resolved in the phylogenetic tree reconstructions (Figs. 2 and 3): Brachythemis impartita (Karsch, 1890), Orthetrum cancellatum (Linnaeus, 1758), Platycnemis pennipes (Pallas, 1771), Pyrrhosoma nymphula (Sulzer, 1776), Sympetrum striolatum (Charpentier, 1840).

Molecular divergence estimates based on all records with a COI sequence length $>500$ bp (640 specimens, 87 species) and the K2P-model revealed a mean minimum intraspecific divergence of $0.39 \%(0-9.45 \% ; 0.79 \mathrm{SD}$; Supplementary file S2). Inspection of the pairwise distances showed that the extreme maximum value is due to one Chalcolestes viridis Vander Linden, 1825 (ZPLOD168-20), which is placed in the C. parvidens (Artobolevskii, 1929) cluster in the MLtree (Fig. 2; see discussion for further details). Excluding this specimen from the pairwise distance calculations resulted in a mean minimum intraspecific divergence of $0.37 \%(0-4.69 \%$; $0.67 \mathrm{SD})$.

The mean minimum K2P-distance to each nearest neighbor (NN) species (excluding specimen ZPLOD168-20) was $8.69 \%(0-17.9 \%$; $5.03 \mathrm{SD})$ and thus on average 23.5 times the mean intraspecific divergence indicating the presence of a DNA barcode gap between the majority of the studied species (NN distance $>0$ in 95 species; Supplementary file S2). This estimate, however, might be inflated by the 15 singleton species and only 20 species with 10 or more individuals (although 54 species were represented by individuals from 2 or more countries). Within genus level sequence divergence was expectedly smaller (9.44-18.34\%) than within family level (17.21-25.39\%).

The highest intraspecific variation was observed in Cordulia aenea (4.69\%; see also Supplementary file S2), which was also assigned to two different BINs (Fig. 1). Elevated levels of intraspecific variation were also evident in Onychogomphus forcipatus (Linnaeus, 1758)

Peer) reviewing PDF | (2020:08:52354:1:1:NEW 11 Feb 2021) 
355 (2.97\%), but all 17 specimens from 4 countries were, however, united in one common BIN 356 (BOLD:AAE5061).

357 While the ML bootstrap support for most genus and species level nodes was generally high 358 (>95), family-level and inter-generic relationships were only poorly or not at all supported (Figs.

3591 \& 2). The latter was more pronounced in dragonflies, but also in damselflies several families 360 were not resolved as monophyletic units.

361

362 Discussion

363 DNA barcoding is a well-established and powerful tool for quickly gaining preliminary

364

365

366

367

368

369

370

371

372

373

374

375

376

377

378

379

380

381

382

383

384

385

386

387

388

389

390

391

392

393 information on the taxonomic status of certain taxa and for assigning problematic specimens, unidentifiable life stages or sexes, or tissue samples to particular species (Hajibabaei et al., 2007; Valentini, Pompanon \& Taberlet, 2008; Hubert \& Hanner, 2015). This, however, only works when a comprehensive reference database covering the relevant taxa is available and accessible.

The comparison of the success rates for the generation of DNA barcodes for Odonata shows that the standard protocols with highly universal PCR primers (LCO1490 + HCO2198 or LCO1490$\mathrm{JJ}+\mathrm{HCO} 2198-\mathrm{JJ}$ ) performed worse than the approaches with Odonata specific primer combinations (Tyr-Odo-F + Leu-Odo-R, CO1-Odo-F5 + CO1-Odo-R6 or ODO_LCO1490d + ODO_HCO2198d). While this is important for targeted, efficient filling of taxonomical gaps with new COI data, it has also implications for routine molecular identification projects where the sub-optimal primer binding might lead to false negative results in a given sample. Yet, the finding that all 39 records with partial DNA barcodes ( $29<400 \mathrm{bp} ; 10<500 \mathrm{bp}$ ) have been assigned successfully to a conspecific BIN cluster (Supplementary file S3) demonstrates that 'minibarcodes' - more suitable for metabarcoding-based community assessments - have the potential to correctly identify Odonata DNA traces. This finding is in line with several recent studies employing partial COI-based DNA metabarcoding for freshwater community assessments (e.g., Sun et al., 2019; Zizka, Geiger \& Leese, 2020).

With the publication of this study together with the examined DNA barcodes we increase the percentage of European dragonflies covered in the reference library to $71 \%$ (103 of 145 species; Boudot \& Kalkman, 2015; with addition in: Viganò, Janni, \& Corso, 2017; Lopez-Estrada et al., 2020) considering a threshold of one specimen per species. $88.3 \%$ of the 103 species included herein could be readily identified at a European scale, using their DNA barcodes and the reference dataset provided. The rate is even higher if instances of very obvious misidentifications or mis-labelled sequence depositions in BOLD or GenBank are removed (see Table 2). Because most cases of BIN sharing involve allopatric or parapatric species (Table 1), the re-identification success in the field or at national and regional scales is certainly higher. In fact, only two groups with five species involved broadly co-occur naturally in the field in Europe: Anax imperator Leach, 1815 and A. parthenope (Selys, 1839) and three Coenagrion 
394

395

396

397

398

399

400

401

402

403

404

405

406

407

408

409

410

411

412

413

414

415

416

417

418

419

420

421

422

423

424

425

426

427

428

429

430

431

432

species (i.e., C. pulchellum (Vander Linden, 1825), C. puella (Linnaeus, 1758), and C. ornatum (Selys, 1850)).

While shallow genetic distances and sporadic haplotype sharing prevented the unambiguous identification in 12 species taking into account the full dataset (5 of 7 BINs in Table 1), low but consistent mitochondrial differentiation allows for an unambiguous identification in the remaining two BINs (Anax imperator / A. parthenope and Gomphus schneiderii Selys, 1850 / G. vulgatissimus (Linnaeus, 1758); Figure 4 and Supplementary file S3).

The observed identification success rate is comparable to findings from other DNA barcoding studies on dragonflies and damselflies (95\% in a set of 51 species from Europe and Africa, Bergmann et al., 2013; 79-94\%, depending on the criteria used, in a set of 38 species from Brazil, Koroiva et al., 2017; 89\% in 38 species from the Philippines, Casas et al., 2018; 85\% in a set of 88 species from Italy, Galimberti et al., 2020; $80 \%$ of ten species from Malta, Rewicz et al., 2020). The rate is also similar to other insect taxa such as Coleoptera ( $92 \%$; Hendrich et al., 2015), Neuroptera (90\%; Morinière et al., 2014), Heteroptera (92\%; Raupach et al., 2014) or tachinid flies (93\%; Pohjoismäki, Kahanpää \& Mutanen, 2016), considerably better than for Caelifera (59\%; Hawlitschek et al., 2016), but not as good as for e.g. Lepidoptera (99\%; Huemer et al., 2014), apoid wasps (99\%; Schmid-Egger et al., 2019), or Ensifera (100\%; Hawlitschek et al., 2017).

Thus, except for a few cases, DNA barcodes can discriminate between dragon- and damselfly species, making identification through DNA barcoding trustworthy. The relationships between higher taxonomic ranks, such as families and sometimes even genera, on the other hand, were often not resolved as phylogenetically meaningful monophyla (Figs. $1 \& 2$; Supplementary file S3), with nearest neighbors in the revealed ML-topologies sometimes belonging to taxonomically very distant groups. This, however, is not unexpected, considering that the high substitution rate of mitochondrial genes, which allows for discrimination among species, implies an increased probability of loss of informative characters (saturation) at deeper nodes (e. g., Morgan, Creevey \& O'Connell, 2014). Thus, inferring robust phylogenetic hypotheses among species and genera must involve sequencing of a much higher number of mitochondrial and/or independently evolving nuclear genetic markers. However, this also means that reliable identification to genus level for species not present in the reference library is difficult for some groups (Ekrem, Willassen \& Stur, 2007).

Since our dataset includes only a fraction of the entire distribution ranges of many dragonfly and damselfly species, the estimates of intraspecific divergence are not representative for the entire diversity within each species. Consequently, the inferred DNA barcode gaps are very likely an overestimate. Nonetheless, considering the relatively high between-species differentiation observed (mean $8.69 \% \mathrm{~K} 2 \mathrm{P}$ ) we are confident that this will also hold true when DNA barcodes of a geographically broader set of individuals are available for all species. 
433 BIN sharing among species. Cases of BIN sharing (i.e. a lack of a DNA barcode gap) were rare 434 (Tables $1 \&$ 2; Supplementary file S2) and concerned three species triplets and five species pairs. 435 Full barcode/haplotype sharing (distance to nearest neighbor $=0$ ) was observed only among i) 436 Calopteryx splendens (Harris, 1782) and C. xanthostoma Charpentier, 1825, ii) Coenagrion 437 ornatum, C. puella and C. pulchellum, and iii) Ischnura saharensis Aguesse, 1958 and I.

438 elegans. However, only in species belonging to Coenagrion this might hamper an identification 439 via COI data at certain locations of co-occurrence, as the other two species should not occur 440 sympatrically except in Liguria (North-West Italy) and France (Boudot \& Kalkman, 2015). In

441

442

443

444

445

446

447

448

449

450

451

452

453

454

455

456

457

458

459

460

461

462

463

464

465

466

467

468

469

470

471

472 general, cases of BIN sharing among species might be explained by mitochondrial introgression following hybridization, recent divergence with or without incomplete lineage sorting (ILS) or inadequate taxonomy and misidentification (Kerr et al., 2007; Ward, Hanner \& Hebert, 2009; Zangl et al., 2020). The latter can probably be excluded as a source for the observed cases of BIN and haplotype sharing in our study, as most central and northern European Odonata species are easy to identify based on morphological characters and coloration of adults. This is also true for the species that share BINs. Recently, progress has been made in screening odonates for endosymbionts such as Wolbachia or Rickettsia, for example in Coenagrion from the UK (Thongprem et al 2020), or from systems outside of our study area (Lorenzo-Carballa et al 2019 - Fiji archipelago; Salunkhe et al 2015 - Central India), documenting that these endosymbionts could constitute another route for mitochondrial introgression between species.

In Calopteryx splendens and C. xanthostoma, BIN sharing might be due to recent divergence and/or hybridization. The two species are evidently closely related (Weekers et al., 2001). They have largely non-overlapping distributions, but there is evidence for hybridization in regions where they co-occur (Dumont, Mertens \& De Coster, 1993). This seems to also occur sporadically among more distantly related taxa. For example, $C$. haemorrhoidalis (Vander Linden, 1825) and C. splendens (Lorenzo-Carballa, Watts \& Cordero-Rivera, 2014) and $C$. splendens and C. virgo (Linnaeus, 1758) hybridize in at least parts of the region studied herein (Tynkkynen et al., 2008; Keränen et al., 2013).

The genus Chalcolestes includes two BINs, one comprised of $C$. viridis, the other containing $C$. parvidens and one individual of $C$. viridis (also see Galimberti et al., 2020). These results could be due to introgressive hybridization (Supplementary file S3). The two species are morphologically very similar, but do differ in a few characters. Intermediate morphotypes have been reported, mainly from regions where the distribution ranges overlap (Olias et al., 2007). Yet, a previous study looking at morphological and genetic differentiation between $C$. parvidens and $C$. viridis in southeastern Europe did not find evidence for hybridization between the two species, suggesting that the intermediate morphotypes are intraspecific variation (Gyulavári et al., 2011). As Gyulavári et al. (2011) used only a handful of specimens for molecular genetic analyses, the apparent lack of hybridization evidence is not surprising. Where the two species cooccur, there appears to be some prezygotic isolation by temporal segregation in their daily reproductive activities (Dell'Anna et al., 1996). 
473 Within Coenagrion, previous studies have already reported mitochondrial haplotype sharing

474 between C. puella and C. pulchellum in England and as morphological characters were

475 sometimes shared between the two species, the observed haplotype sharing was initially

476 attributed to hybridization (Freeland \& Conrad, 2002). Subsequent genetic analyses based on

477 nuclear microsatellite markers, however, found no evidence for hybridization between these two

478 species (Lowe et al., 2008). Whether this pattern is true for the species' entire distribution range

479 remains to be seen, but BIN sharing and haplotype sharing between C. puella, C. pulchellum and

480 C. ornatum across large geographic regions - England, Germany, Norway (Freeland \& Conrad,

481 2002, this study) - argue against localized hybridization/introgression events and might indicate

482 either very recent species divergence with ILS or rapid, potentially range-wide, mitochondrial

483 replacement following fairly recent introgression. Our geographically limited sampling does not

484 permit us to infer the direction of potential introgression with confidence, but the higher genetic

485 diversity in C. pulchellum might be an indication that it is the donor species (Supplementary files

486 S2 and S3). To distinguish between the two alternative scenarios (ILS and mitochondrial

487 replacement), a geographically more comprehensive sample and nuclear multilocus sequence

488 data is required. Recently, in a preliminary analysis, Galimberti et al. (2020, Appendix S7

489 therein) found the three species to be well separated at three nuclear loci.

490 BIN- and haplotype sharing among species of Ischnura (I. elegans, I. genei (Rambur, 1842), I.

491 saharensis) was to be expected (see also Rewicz et al., 2020). Together with I. graellsii

492 (Rambur, 1842) (not included in our dataset), these species constitute a probably recent radiation

493 around the western Mediterranean basin, with I. elegans distributed mostly northeast of the

494 Pyrenees across large parts of Europe, I. graellsii south of the Pyrenees to the Atlas, I. saharensis

495 southeast of that, and I. genei on the Tyrrhenian islands (Dijkstra \& Kalkman, 2012). In the few

496 regions where two of the species meet, hybridization has been reported (e.g., Monetti,

497 Sánchez-Guillén \& Cordero-Rivera, 2002, Sánchez-Guillén et al., 2011, 2014, Wellenreuther et

498 al., 2018). Hence, both recent divergence and introgression might underlie the observed BIN

499 sharing in this species group.

500

501 In dragonflies a very shallow divergence with BIN (and even haplotype) sharing has been

502 recently reported for A. imperator and A. parthenope (Galimberti et al., 2020; Rewicz et al., 503 2020). We also find that these species share one BIN, but unlike the two previously mentioned

504 studies that focused on southern Europe, we do not find evidence for haplotype sharing in our

505 Central European data (Fig. 4). However, our sampling is far from being exhaustive and it might

506 well be that hybridization/introgression is also common in Central European Anax Leach, 1815.

507 Hitherto, the two species have only been included in a single phylogenetic analysis based on a

508 single nuclear marker (Letsch et al., 2009), and divergence between them was much deeper than

509 between other aeshnid species that are resolved as distinct BINs in our (and other) DNA

510 barcoding datasets. This deeper divergence in the nuclear data would suggest that the observed

511 BIN sharing of the two Anax species is indeed due to mitochondrial introgression. However, to

512 conclusively test whether the observed patterns of shallow mitochondrial divergence are due to 
513 recent origin or hybridization remains to be studied by means of nuclear multilocus or genome 514 scale data.

515 BIN sharing was also observed between Gomphus schneiderii and G. vulgatissimus (Fig. 2 and 516 Supplementary file S3). In Europe, G. schneiderii is restricted to the Balkans, whereas $G$.

517 vulgatissimus is found across large parts of Europe, overlapping with G. schneiderii in some 518 Balkan regions (De Knijf, Vanappelghem \& Demolder, 2013). So far, there is no evidence for 519 hybridization between these two species. Even though they share a BIN, low but consistent 520 mitochondrial differentiation allows unambiguous identification.

521 BIN sharing was also found among Somatochlora meridionalis Nielsen, 1935 and S. metallica

522 (Vander Linden, 1825) (Fig. 2 and Supplementary file S3; also see Galimberti et al., 2020).

523 Although $S$. meridionalis has its main area of distribution in the Balkans and Italy and $S$.

524 metallica is mainly found from Central and northern Europe to Siberia, their distribution areas do 525 overlap in Central Europe and the Balkans. The two species are morphologically very similar, 526 but show small but consistent differences in larval morphology and adult coloration

527 (Seidenbusch, 1996; Boudot \& Kalkman, 2015). This has previously led to the suggestion that

528 they should indeed be regarded as distinct species despite BIN sharing and the presence of

529 intermediate phenotypes in regions of sympatric occurrence (Fleck, Grand \& Boudot, 2007). Yet, 530 nuclear multilocus data are required to resolve the phylogenetic relationships and the extent of 531 inter-specific gene flow in this species pair.

532

533 Problems with morphological species identification might arise in European regions not covered 534 by our study, especially in southern Europe. In these regions, several morphologically similar 535 species co-occur, some of which are included in our dataset, that are not only more difficult to 536 identify but might also hybridize (e.g., Ischnura elegans x I. graellsii, Sánchez-Guillén, Van 537 Gossum \& Cordero-Rivera, 2005; Sánchez-Guillén et al, 2011; Calopteryx spp., Dumont, 538 Mertens \& De Coster, 1993, Weekers, De Jonckheere \& Dumont, 2001, Lorenzo-Carballa, Watts 539 \& Cordero-Rivera, 2014; Cordulegaster trinacriae Waterston, 1976 x C. boltonii (Donovan, 540 1807), Solano et al. 2018).

541

542 Deep intraspecific divergence. Whereas the aforementioned species shared DNA barcodes, 543 only one species, Cordulia aenea, showed considerable intraspecific sequence divergence. For 544 this species, two deeply divergent clades (up to $4.7 \%$ inter-clade K2P divergence) were 545 recovered. One of these two clades includes specimens from Norway, France and Germany, 546 whereas the other one contains specimens from Norway and Poland. Hence, these two clades do 547 not reflect a clear geographic separation. Interestingly, though, this second $C$. aenea clade groups 548 with C. amurensis Selys, 1887 from Japan (Fig. 5). Currently, Cordulia is considered to 549 comprise three species, C. aenea, C. amurensis and C. shurtleffii Scudder, 1866. In western 550 Eurasia, only C. aenea has been reported thus far, with C. amurensis restricted to far eastern Asia 551 and $C$. shurtleffii present in North America. Throughout their distribution range, Cordulia spp.

552 show quite some variation, but no clear inter-specific differences in morphology, behavior or 
553 ecology are known (Dijkstra \& Kalkman, 2012), apart from a slightly smaller size of $C$.

554 amurensis as compared to C. aenea (Jödicke, Langhoff \& Misof, 2004) which questioned the

555 validity of the three allopatrically distributed species (Kosterin \& Zaika, 2010). However, deeply

556 divergent, geographically restricted nuclear genetic lineages were found supporting the existence

557 of three distinct Cordulia species in western Eurasia, far eastern Asia and North America,

558 respectively (Jödicke, Langhoff \& Misof, 2004).

559 Similar cases of surprisingly high intraspecific divergence were recently observed by Galimberti

560 et al. (2020) for different European populations of Erythromma lindenii (Selys, 1840) (up to

$5614.8 \%$ inter-clade K2P divergence) and Coenagrion mercuriale (Charpentier, 1840) populations

562 highly divergent from other European and North African populations (up to 8\% K2P distance).

563 Whether these cases will lead to the formal recognition of species ranks for neglected subspecies

564 need further studies.

565

566

567

\section{Conclusions}

568

569

In this study, we provide the first comprehensive reference DNA barcode collection for central and northern European dragon- and damselflies. We found only five instances of BIN sharing

570 preventing a ready identification of the involved 12 species and one case of deep intraspecific

571 divergence (two BINs for a single species). This implies that the vast majority of central and

572 northern European dragon- and damselflies can be readily identified based on DNA barcodes.

573 While adults may be easily identified by morphological characteristics and color patterns,

574 identification of larvae is often not trivial. As odonates are considered good indicators of

575 environmental health and flagship species for other threatened taxa, and are being used to

576 prioritize areas for conservation action (Lemelin, 2007; Simaika \& Samways, 2009; Clausnitzer

577 et al., 2017), reliable species identification is pivotal. The reference DNA barcode data now

578 serve as a basis for a rapid and reliable identification of material/life stages hitherto difficult to

579 identify and community assessments via environmental metabarcoding. The cases with BIN

580 sharing should be considered in applications of DNA barcoding and metabarcoding. These, as

581

582

583

584

585

586

587

588

589

590

591

592 well as those with deep intraspecific divergence represent interesting evolutionary biological questions and call for an in depth analysis throughout the species' distribution ranges by means of nuclear multilocus or genomic data.

\section{Acknowledgements}

This study is a result of several long lasting, comprehensive DNA Barcode of Life campaigns (ABOL - Austria; BFB - Bavaria; GBOL - Germany; NorBOL - Norway; PolBOL - Poland), which were only possible with the aid of numerous taxonomic experts and behind-the-scene working logistic helpers. At ZFMK we are indebted to Jana Thormann, Laura von der Mark, Simone Behrens-Chapuis, Moritz Fahldieck, Morris Flecks, Thierry Sellmeier, Wolfgang Wägele and Bernhard Misof. We thank Frank Petzold, Stefan V. Ober and Michael Franzen for 
593 contributing to the national DNA barcoding campaigns with their expertise. Jon Kristian Skei, 594 Dag Dolmen, and Steffen Roth are thanked for contributions in sampling and with their expertise 595 in identification of specimens. We are grateful to the research team at BIO and CCDB in Guelph 596 (Ontario, Canada) for their great support and help and particularly to Sujeevan Ratnasingham for 597 developing the BOLD database (BOLD; www.boldsystems.org) infrastructure and the BIN 598 management tools. The sequencing work was supported, in part, by funding from the 599 Government of Canada to Genome Canada through the Ontario Genomics Institute, while the 600 Ontario Ministry of Research and Innovation and NSERC supported the development of the 601 BOLD informatics platform.

602

603

604

605

606

607

608

609

Astrin JJ, Höfer H, Spelda J, Holstein J, Bayer S, Hendrich L, Huber BA, Kielhorn KH,

610 Krammer HJ, Lemke M, Monje JC, Morinière J, Rulik B, Petersen M, Janssen H, Muster C.

611 one, 11(9), e0162624.

612 DOI: 10.1371/journal.pone.0162624

613

614 Becker S, Hanner R, Steinke D. 2011. Five years of FISH-BOL: brief status report.

615 Mitochondrial DNA, 22(sup1), 3-9.

616 DOI: $10.3109 / 19401736.2010 .535528$

617

618 Bergmann T, Rach J, Damm S, DeSalle R, Schierwater B, Hadrys H. 2013. The potential of 619 distance-based DNA barcoding for defining problematic taxonomic entities by COI and ND1. 620 Molecular Ecology Resources 13: 1069-1081.

621 DOI: $10.1111 / 1755-0998.12125$

622

623

Bergsten JD, Bilton T, Fujisawa T, Elliott M, Monaghan MT, Balke M, Hendrich L, Geijer J, 624 Herrmann J, Foster GN, Ribera I, Nilsson AN, Barraclough TG, Vogler AP. 2012. The Effect of

625 Geographical Scale of Sampling on DNA Barcoding. Syst Biol 61(5):851-869

626 DOI: $10.1093 /$ sysbio/sys037

627

628 Boudot JP, Kalkman VJ. 2015. Atlas of the European dragonflies and damselflies. KNNV

629 Publishing. The Netherlands.

630 
631 Casas PAS, Sing K-W, Lee P-S, Nuñeza OM, Villanueva RJT, Wilson J-J. 2018. DNA barcodes 632 for dragonflies and damselflies (Odonata) of Mindanao, Philippines. Mitochondrial DNA Part A 633 29: 206-211.

634 DOI: $10.1080 / 24701394.2016 .1267157$

635

636 Chovanec A, Waringer J. 2015. Colonization of a 3rd order stream by dragonflies (Insecta:

637 Odonata)-a best practice example of river restoration evaluated by the Dragonfly Association 638 Index (lower Weidenbach, eastern Austria). Acta ZooBot Austria, 152, 89-105.

639

640 Clausnitzer V, Simaika JP, Samways MJ, Daniel BA. 2017. Dragonflies as flagships for 641 sustainable use of water resources in environmental education. Applied Environmental

642 Education \& Communication 16: 196-209.

643 DOI: $10.1080 / 1533015 X .2017 .1333050$

644

645 Collins RA, Cruickshank RH. 2013. The seven deadly sins of DNA barcoding. Molecular 646 ecology resources, 13(6), 969-975.

647 DOI: $10.1111 / 1755-0998.12046$

648

649 Damm S, Schierwater B, Hadrys H. 2010. An integrative approach to species discovery: from 650 character-based DNA barcoding to ecology. Molecular Ecology, 19, 3881- 3893.

651 DOI: $10.1111 /$ j.1365-294X.2010.04720.x

652

653 De Knijf G, Vanappelghem C, Demolder H. 2013. Odonata from Montenegro, with notes on 654 taxonomy, regional diversity and conservation. Odonatologica, 42(1), 1-29.

655

656

Dell'Anna L, Utzeri C, De Matthaeis E, Cobolli M. 1996. Biological differentiation and

657 reproductive isolation of syntopic central Italian populations of Chalcolestes viridis (Vander L.)

658 and C. parvidens (Artobol.) (Zygoptera:Lestidae). Notulae Odonatologicae, 4: 135-136.

659

660

Dijkstra K-DB, Kalkman VJ. 2012. Phylogeny, classification and taxonomy of European

661 dragonflies and damselflies (Odonata): a review. Organisms, Diversity and Evolution 12: 209-

662227.

663 DOI: $10.1007 / \mathrm{s} 13127-012-0080-8$

664

665

Dijkstra KDB, Kalkman VJ, Dow RA, Stokvis FR, Van Tol JAN. 2014. Redefining the

666 damselfly families: a comprehensive molecular phylogeny of $Z$ ygoptera (Odonata). Systematic

667 Entomology, 39(1), 68-96.

668 DOI: $10.1111 /$ syen.12035

669 
670 Duftner N, Koblmüller S, Sturmbauer C. 2005. Evolutionary relationships of the Limnochromini, 671 a tribe of benthic deepwater cichlid fish endemic to Lake Tanganyika, East Africa. Journal of

672 Molecular Evolution 60: 277-289.

673 DOI: $10.1007 / \mathrm{s} 00239-004-0017-8$

674

675 Dumont HJ, Mertens J, De Coster W. 1993. The Calopteryx splendens-cline in southwestern

676 France, analysed by quantitative wingspot analysis (Zygoptera: Calopterygidae). Odonatologica

677 22: $345-351$.

678

679 Ekrem T, Willassen E, Stur E. 2007. A comprehensive DNA sequence library is essential for 680 identification with DNA barcodes. Mol Phylogenet Evol 43(2):530-542

681 DOI: 10.1016/j.ympev.2006.11.021

682

683

Elbrecht V, Vamos EE, Meissner K, Aroviita J, Leese F. 2017. Assessing strengths

684 and weaknesses of DNA metabarcoding-based macroinvertebrate identification for

685 routine stream monitoring. Methods Ecol. Evol. 8, 1265-1275.

686 DOI: $10.1111 / 2041-210 X .12789$

687

688

Fleck G, Grand D, Boudot JP. 2007. Description of the last stadium larva of Somatochlora

689 borisi, with comparison to that of Somatochlora metallica meridionalis (Odonata: Corduliidae).

690 International Journal of Odonatology 10: 43-52.

691 DOI: $10.1080 / 13887890.2007 .9748287$

692

693

Freeland JR, Conrad KF. 2002. Genetic similarity within and among populations of Variable and

694 Azure damselflies (Coenagrion pulchellum and C. puella). Hydrobiologia 479: 69-73.

695 DOI: 10.1023/A:1021058231151

696

697 Fujita, MK, Leaché AD, Burbrink FT, McGuire JA, Moritz C. 2012. Coalescent-based species

698 delimitation in an integrative taxonomy. Trends in ecology \& evolution, 27(9), 480-488.

699 DOI: $10.1016 /$ j.tree.2012.04.012

700

701 Galimberti A, Assandri G, Maggioni D, Ramazzotti F, Baroni D, Bazzi G, Chiandetti I., Corso

702 A, Ferri V, Galuppi M, Ilahiane L, La Porta G, Laddaga L, Landi F, Mastropasqua F, Ramellini

703 S, Santinelli R, Soldato G, Surdo S, Casiraghi M. 2021. Italian Odonates in the Pandora's Box: A

704 Comprehensive DNA Barcoding Inventory Shows Taxonomic Warnings at the Holarctic Scale.

705 Molecular Ecology Resources, 21: 183-200.

706 DOI: 10.1111/1755-0998.13235.

707

708 Garrison RW, von Ellenrieder N, Louton JA. 2006. Dragonfly Genera of the New World: An

709 Illustrated and Annotated Key to the Anisoptera. JHU Press. 
710

711 Geiger MF, Herder F, Monaghan MT, Almada V, Barbieri R, Bariche M, Berrebi P, Bohlen J,

712 Casal-Lopez M, Delmastro GB, Denys GPJJ, Dettai A, Doadrio I, Kalogianni E, Kärst H,

713 Kottelat M, Kovačić M, Laporte M, Lorenzoni M, Marčić Z, Özuluğ M, Perdices A, Perea S,

714 Persat H, Porcelotti S, Puzzi C, Robalo J, Šanda R, Schneider M, Šlechtová V, Stoumboudi M,

715 Walter S, Freyhof J. 2014. Spatial heterogeneity in the Mediterranean Biodiversity Hotspot

716 affects barcoding accuracy of its freshwater fishes. Molecular ecology resources 14:1210-21.

717 DOI: $10.1111 / 1755-0998.12257$

718

719 Good JM, Vanderpool D, Keeble S, Bi K. 2015. Negligible nuclear introgression despite

720 complete mitochondrial capture between two species of chipmunks. Evolution 69: 1961-1972.

721 DOI: $10.1111 /$ evo.12712

722

723 Gyulavária HA, Felföldib T, Benkenc T, Szabóa LJ, Miskolczia M, Cserhátid C, Horvaie V,

724 Márialigetib K, Dévaia G. 2011. Morphometric and molecular studies on the populations of the

725 damselflies Chalcolestes viridis and C. parvidens (Odonata, Lestidae). International Journal of

726 Odonatology 329-339.

727 DOI: $10.1080 / 13887890.2011 .651983$

728

729 Haase P, Sundermann A, Schindehütte K. 2006. Operationelle Taxaliste als Mindestanforderung

730 an die Bestimmung von Makrozoobenthosproben aus Fließgewässern zur Umsetzung der EU-

731 Wasserrahmenrichtlinie in Deutschland. Essen: University of Duisburg-Essen. Available from:

732 http://gewaesserbewertung.de/files/operationelle taxaliste_2019.xlsx

733

734 Hajibabaei M, Singer GAC, Hebert PDN, Hickey DA. 2007. DNA barcoding: How it

735 complements taxonomy, molecular phylogenetics and population genetics. Trends in Genetics

736 23: 167-172.

737 DOI: 10.1016/j.tig.2007.02.001

738

739 Hajibabaei M, Shokralla S, Zhou X, Singer GAC, Baird DJ. 2011. Environmental Barcoding: A

740 Next Generation Sequencing approach for biomonitoring applications using river benthos. PLoS

741 ONE,6(4): e17497.

742 DOI: 10.1371/journal.pone.0017497.

743

744 Hajibabaei M, Spall JL, Shokralla S, van Konynenburg S. 2012. Assessing biodiversity of a

745 freshwater benthic macroinvertebrate community through non-destructive environmental

746 barcoding of DNA from preservative ethanol. BMC Ecol. 12: 28.

747 DOI: $10.1186 / 1472-6785-12-28$.

748 
749 Haring E, Fischer I, Sittenthaler M, Wolf P, Chovanec A, Koblmüller S, Sattmann H, Beqiraj S, 750 Pesic V, Zangl L. 2020. Intraspecific genetic diversity in selected widespread dragonfly species 751 (Insect: Odonata). Acta ZooBot Austria 157: 243-260.

752

753 Hausmann A, Godfray HCJ, Huemer P, Mutanen M, Rougerie R, van Nieukerken EJ,

754 Ratnasingham S, Hebert PDN. 2013. Genetic Patterns in European Geometrid Moths Revealed 755 by the Barcode Index Number (BIN) System. PLOS ONE 8(12): e84518.

756 DOI: 10.1371 /journal.pone.0084518

757

758

759

Hawlitschek O, Morinière J, Lehmann GUC, Lehmann AW, Kropf M, Dunz A, Glaw F, Detcharoen M, Schmidt S, Hausmann A, Szucsich NU, Caetano-Wyler SA, Haszprunar G. 2017.

760 DNA barcoding of crickets, katydids and grasshoppers (Orthoptera) from Central Europe with

761 focus on Austria, Germany and Switzerland. Molecular Ecology Resources 17: 1037-1053.

762 DOI: $10.1111 / 1755-0998.12638$

763

764

Hendrich L, Morinière J, Haszprunar G, Hebert PD, Hausmann A, Köhler F, Balke M. 2015. A

765 comprehensive DNA barcode database for Central European beetles with a focus on Germany: 766 adding more than 3500 identified species to BOLD. Molecular Ecology Resources 15: 795-818.

767 DOI: $10.1111 / 1755-0998.12354$

768

769

Hernández-Triana LM, Prosser SW, Rodríguez-Perez MA, Chaverri LG, Hebert PDN, Ryan

770 Gregory T. 2014. Recovery of DNA barcodes from blackfly museum specimens (Diptera:

771 Simuliidae) using primer sets that target a variety of sequence lengths. Molecular Ecology

772 Resources 14: 508-518.

773 DOI: $10.1111 / 1755-0998.12208$.

774

775

Hubert N, Hanner R. 2015. DNA Barcoding, species delineation and taxonomy: a historical

776 perspective. DNA Barcodes 33: 44-58.

777 DOI: $10.1515 /$ dna-2015-006

778

779 Huemer P, Mutanen M, Sefc KM, Hebert PDN 2014. Testing DNA barcode performance in 1000 780 species of European Lepidoptera: large geographic distances have small genetic impacts. PloS 781 One 9: e115774.

782 DOI: 10.1371/journal.pone.0115774

783

784

Ivanova NV, Zemlak TS, Hanner RH, Hebert PDN 2007. Universal primer cocktails for fish

785 DNA barcoding. Molecular Ecology Notes, 7(4), 544-548.

786 DOI: $10.1111 / \mathrm{j} .1471-8286.2007 .01748 . \mathrm{x}$

787 
788

789

790

791

792

793

794

795

796

797

798

799

800

801

802

803

804

805

806

807

808

809

810

811

812

813

814

815

816

817

818

819

820

821

822

823

824

825

826

827

Jödicke R, Langhoff P, Misof B. 2004. The species-group taxa in the Holarctic genus Cordulia: a study in nomenclature and genetic differentiation (Odonata: Corduliidae). International Journal of Odonatology 7: 37-52.

DOI: $10.1080 / 13887890.2004 .9748193$

Kalkman VJ, Clausnitzer V, Dijkstra KDB, Orr AG, Paulson DR, van Tol J. 2008. Global diversity of dragonflies (Odonata) in freshwater. In Freshwater animal diversity assessment (pp. 351-363). Springer, Dordrecht.

DOI: $10.1007 / \mathrm{s} 10750-007-9029-\mathrm{x}$

Kalkman VJ, Boudot J-P, Bernard R, Conze K-J, De Knijf G, Dyatlova E, Ferreira S, Jović M, Ott J, Riservato E, Sahlén G. 2010. European Red List of Dragonflies.

Luxembourg: Publications Office of the European Union.

Kalyaanamoorthy S, Minh BQ, Wong TKF, von Haeseler A, Jermiin LS. 2017. ModelFinder: fast model selection for accurate phylogenetic estimates. Nature Methods 14: 587-589.

DOI: $10.1038 / \mathrm{nmeth} .4285 \mathrm{z}$

Kerr KCR, Stoeckle MY, Dove CJ, Weigt LA, Frances CM, Hebert PDN. 2007. Comprehensive DNA barcode coverage of North American birds. Molecular Ecology Notes 7: 535-545.

DOI: $10.111 / \mathrm{j} .1471-8286.2007 .01670 . \mathrm{x}$

Keränen I, Kahilainen A, Knott KE, Kotiaho JS, Kuitunen K. 2013. High maternal species density mediates unidirectional heterospecific matings in Calopteryx damselflies. Biological Journal of the Linnean Society, 108, 534-545.

DOI: $10.1111 / \mathrm{j} .1095-8312.2012 .02043 . \mathrm{x}$

Koblmüller S, Salzburger W, Obermüller B, Eigner E, Sturmbauer C, Sefc KM. 2011. Separated by sand, fused by dropping water: habitat barriers and fluctuating water levels steer the evolution of rock-dwelling cichlid populations. Molecular Ecology 20: 2272-2290.

DOI: $10.1111 / \mathrm{j} .1365-294 X .2011 .05088 . \mathrm{x}$

Koblmüller S, Nevado B, Makasa L, Van Steenberge M, Vanhove MPM, Verheyen E, Sturmbauer C, Sefc KM. 2015. Phylogeny and phylogeography of Altolamprologus: ancient introgression and recent divergence in a rock-dwelling Lake Tanganyika cichlid genus. Hydrobiologia 791: 35-50.

DOI: $10.1007 / \mathrm{s} 10750-016-2896-2$

Koroiva R, Kvist S. 2018. Estimating the barcoding gap in a global dataset of cox1 939 sequences for Odonata: close, but no cigar. Mitochondrial DNA Part A, 29(5), 765-771.

Peer) reviewing PDF | (2020:08:52354:1:1:NEW 11 Feb 2021) 
828

829

830

831

832

833

834

835

836

837

838

839

840

841

842

843

844

845

846

847

848

849

850

851

852

853

854

855

856

857

858

859

860

861

862

863

864

865

866

867

DOI: $10.1080 / 24701394.2017 .1357709$

Koroiva R, Pepinelli M, Rodrigues ME, de Oliveira Roque F, Lorenz-Lemke AP, Kvist S. 2017. DNA barcoding of odonates from the Upper Plata basin: database creation and genetic diversity estimation. PloS One 12: e0182283.

DOI: 10.1371/journal.pone.0182283

Kosterin OE, Zaika VV. 2010. Odonata of Tuva, Russia. International Journal of Odonatology 13: 277-328.

DOI: $10.1080 / 13887890.2010 .9748380$

Leese F, Altermatt F, Bouchez A, Ekrem T, Hering D, Mergen P, Pawlowski J, Piggott J, Abarenkov K, Beja P, Bervoets L, Boets P, Bones A, Borja Á, Bruce K, Carlsson J, Coissac E, Costa F, Costache M, Creer S, Csabai Z, Deiner K, DelValls Á, Duarte S, Fazi S, Graf W, Hershkovitz Y, Japoshvili B, Jones J, Kahlert M, Kalamujic Stroil B, Kelly-Quinn M, Keskin E, Mächler E, Mahon A, Marečková M, Mejdandzic M, Montagna M, Moritz C, Mulk V, Navodaru I, Pálsson S, Panksep K, Penev L, Petrusek A, Pfannkuchen M, Rinkevich B, Schmidt-Kloiber A, Segurado P, Strand M, Šulčius S, Traugott M, Turon X, Valentini A, van der Hoorn B, Vasquez Hadjilyra M, Viguri J, Vogler A, Zegura B. 2016. DNAqua-Net: Developing new genetic tools for bioassessment and monitoring of aquatic ecosystems in Europe. Research Ideas and Outcomes 2:e11321.

DOI: 10.3897/rio.2.e11321

Leese F, Bouchez A, Abarenkov K, Altermatt F, Borja Á, Bruce K, Ekrem T, Čiampor Jr. F, Čiamporová-Zat'ovičová Z, Costa FO, Duarte S, Elbrecht V, Fontaneto D, Franc A, Geiger MF, Hering D, Kahlert M, Stroil BK, Kelly M, Keskin E, Liska I, Mergen P, Meissner K, Pawlowski J, Penev L, Reyjol Y, Rotter A, Steinke D, van der Wal B, Vitecek S, Zimmermann J, Weigand AM. 2018. Why We Need Sustainable Networks Bridging Countries, Disciplines, Cultures and Generations for Aquatic Biomonitoring 2.0: A Perspective Derived From the DNAqua-Net COST Action. Advances in Ecological Research, 58: 63- 99.

DOI: $\underline{10.1016 / \text { bs.aecr.2018.01.001 }}$

Lemelin H. 2007. Finding the beauty in the dragon: the role of dragonflies in recreation and tourism. Journal of Ecotourism 6: 139-145.

DOI: $10.2167 /$ joe 161.0

Leray M, Yang JY, Meyer CP, Mills SC, Agudelo N, Ranwez V, Boehm JT, Machida RJ. 2013. A new versatile primer set targeting a short fragment of the mitochondrial COI region for metabarcoding metazoan diversity: application for characterizing coral reef fish gut contents. Frontiers in Zoology 10:34. 
868

869

870

871

872

873

874

875

876

877

878

879

880

881

882

883

884

885

886

887

888

889

890

891

892

893

894

895

896

897

898

899

900

901

902

903

904

905

906

907

DOI: $10.1186 / 1742-9994-10-34$.

Letsch HO, Greve C, Kück P, Fleck G, Stocsits RR, Misof B. 2009. Simultaneous alignment and folding of 28S rRNA sequences uncovers phylogenetic signal in structure variation. Molecular Phylogenetics and Evolution 53: 758-771.

DOI: $10.1016 /$ j.ympev.2009.07.033

López-Estrada EK, Barona Fernández J, Cardo- Maeso N, Teruel Montejano S, Diaz Martinez C. 2020. Onychogomphus cazuma sp. nov. from Spain: Molecular and morphological evidence supports the discovery of a new European dragonfly species (Odonata: Gomphidae). Odonatologica 49:125-154.

DOI: $10.5281 /$ zenodo.3823337.

Lorenzo-Carballa MO, Torres-Cambas Y, Heaton K, Hurst GDD, Charlat S, Sherratt TN, Van Gossum H, Cordero-Rivera A, Beatty CD. 2019. Widespread Wolbachia infection in an insular radiation of damselflies (Odonata, Coenagrionidae). Scientific reports, 9(1), 1-13.

DOI: 10.1038/s41598-019-47954-3

Lorenzo-Carballa MO, Watts PC, Cordero-Rivera A. 2014. Hybridization between Calopteryx splendens and $C$. haemorrhoidalis confirmed my morphological and genetic analyses.

International Journal of Odonatology 17: 149-160.

DOI: $10.1080 / 13887890.2014 .951696$

Lowe CD, Harvey IF, Thompson DJ, Watts PC. 2008. Strong genetic divergence indicates that congeneric damselflies Coenagrion puella and C. pulchellum (Odonata: Zygoptera:

Coenagrionidae) do not hybridise. Hydrobiologia 605, 55-63.

DOI: $10.1007 / \mathrm{s} 10750-008-9300-9$

Lucas WJ. 1900. British dragonflies (Odonata). - pp. i-xiv [=1-14], 1-356, Pl. I-XXVII [= 1-27]. London. (Gill) [accessed via www.animalbase.uni-goettingen.de July $31^{\text {th }} 2020$ ].

Macher JN, Salis RK, Blakemore KS, Tollrian R, Matthaei CD, Leese F. 2016. Multiple-stressor effects on stream invertebrates: DNA barcoding reveals contrasting responses of cryptic mayfly species. Ecological Indicators 61(2).

DOI: $10.1016 /$ j.ecolind.2015.08.024.

Majaneva M, Diserud OH, Eagle SHC, Boström E, Hajibabaei M, Ekrem T. 2018. Environmental DNA filtration techniques affect recovered biodiversity. Scientific Reports $8: 4682$.

DOI: $10.1038 / \mathrm{s} 41598-018-23052-8$. 
908

909

910

911

912

913

914

915

916

917

918

919

920

921

922

923

924

925

926

927

928

929

930

931

932

933

934

935

936

937

938

939

940

941

942

943

944

945

946 Padial JM, Miralles A, De la Riva IJ, Vences M. 2010. The integrative future of taxonomy.

947 Frontiers in Zoology 7:16.

Mitchell A, Samways MJ 2005. The morphological 'forms' of Palpopleura lucia (Drury) are separate species as evidenced by DNA sequencing (Anisoptera : Libellulidae). Odonatologica, $34,173-178$.

Monetti L, Sánchez-Guillén R, Cordero-Rivera A. 2002 Hybridization between Ischnura graellsii (Vander Linder) and I. elegans (Rambur) (Odonata: Coneagrionidae): are they different species? Biological Journal of the Linnean Society 76: 225-235.

DOI: $10.1111 /$ j.1095-8312.2002.tb02084.x

Morinière J, Balke M, Doczkal D, Geiger MF, Hardulak LA, Haszprunar G, Hausmann A, Hendrich L, Regalado L, Rulik B, Schmidt S, Wägele J, Hebert, PD. 2019. A DNA barcode library for 5,200 German flies and midges (Insecta: Diptera) and its implications for metabarcoding-based biomonitoring. Molecular Ecology Resources.

DOI: $10.1111 / 1755-0998.13022$

Morinière J, Hendrich L, Hausmann A, Hebert P, Haszprunar G, Gruppe A. 2014. Barcoding Fauna Bavarica: $78 \%$ of the Neuropterida fauna barcoded! PloS One 9: e109719.

DOI: 10.1371/journal.pone.0109719

Morgan CC, Creevey CJ, O’Connell MJ. 2014. Mitochondrial data are not suitable for resolving placental mammal phylogeny. Mammalian Genome 25: 636-647.

DOI: $10.1007 / \mathrm{s} 00335-014-9544-9$

Nevado B, Koblmüller S, Sturmbauer C, Snoeks J, Usano-Alemany J, Verheyen E. 2009.

Complete mitochondrial DNA replacement in a Lake Tanganyika cichlid fish. Molecular

Ecology 18: 4240-4255.

DOI: $10.1111 / \mathrm{j} .1365-294 X .2009 .04348 . x$

Nguyen LT, Schmid, HA, von Haeseler A, Minh BW. 2015. IQ-TREE: a fast and effective stochastic algorithm for estimating maximum likelihood phylogenies. Molecular Biology and Evolution 32: 268-274.

DOI: $10.1093 / \mathrm{molbev} / \mathrm{msu} 300$

Olias M, Weihrauch F, Bedjanič M, Hacet N, Marinov M, Šalamun A. 2007. Lestes parvidens and L. viridis in southeastern Europe: a chorological analysis (Odonata: Lestidae). Libellula 26: 243-272.

Peer) reviewing PDF | (2020:08:52354:1:1:NEW 11 Feb 2021) 
948

949

950

951

952

953

954

955

956

957

958

959

960

961

962

963

964

965

966

967

968

969

970

971

972

973

974

975

976

977

978

979

980

981

982

983

984

985

986

DOI: 10.1186/1742-9994-7-16.

Pohjoismäki JLO, Kahanpää J, Mutanen M. 2016. DNA barcodes for the Northern European tachinid flies (Diptera: Tachinidae). PloS One 11: e0164933.

DOI: 10.1371/journal.pone.0164933

Puillandre N, Lambert A, Brouillet S, Achaz G. 2012. ABGD, Automatic Barcode Gap

Discovery for primary species delimitation. Molecular ecology, 21(8), 1864-1877.

DOI: 10.1111/j.1365-294X.2011.05239.x.

Ratnasingham S, Hebert PDN. 2007. BOLD: The Barcode of Life Data System (http://www. barcodinglife. org). Molecular ecology notes, 7(3), 355-364.

DOI: $10.1111 / \mathrm{j} .1471-8286.2007 .01678 . \mathrm{x}$

Ratnasingham S, Hebert PDN. 2013. A DNA-based registry for all animal species: the Barcode Index Number (BIN) system. PloS one, 8(7), e66213.

DOI: 10.1371/journal.pone.0066213.

Raupach MJ, Hendrich L, Küchler SM, Deister F, Morinière J, Gossner MM. 2014. Building-up of a DNA barcode library for true bugs (Insecta: Hemiptera: Heteroptera) of Germany reveals taxonomic uncertainties and surprises. PloS One 9: e106940.

DOI: 10.1371/journal.pone.0106940

Rewicz T, Móra A, Tończyk G, Szymczak A, Grabowski M, Calleja EJ, Pernecker B, Csabai Z. 2020. First records raise questions: DNA barcoding of Odonata in the middle of the

Mediterranean. Genome e-first

DOI: $10.1139 /$ gen-2019-0226

Richlen ML, Barber PH. 2005. A technique for the rapid extraction of microalgal DNA from single live and preserved cells. Molecular Ecology Notes 5: 688-691.

DOI: $10.1111 /$ j.1471-8286.2005.01032.x

Rulik B, Eberle J, von der Mark L, Thormann J, Jung M, Köhler F, Apfel W, Weigel A, Kopetz A, Köhler J, Fritzlar F, Hartmann M, Hadulla K, Schmidt J, Hörren T, Krebs D, Theves F, Eulitz U, Skale A, Rohwedder D, Kleeberg A, Astrin JJ, Geiger MF, Wägele JW, Grobe P, Ahrens D. 2017. Using taxonomic consistency with semi-automated data pre-processing for high quality DNA barcodes. Methods in Ecology and Evolution.

DOI: 10.1111/2041-210X.12824. 
987 Salunkhe RC, Dhotre DP, Salunke BK, Patil VS, Mahale V, Andrew RJ, Patole MS, Narkhede

988 KP, Shouche YS. 2015. Distribution and molecular characterization of Wolbachia

989 endosymbionts in Odonata (Insecta) from Central India by multigene approach. Current Science,

$990,108(5), 971-978$.

991 www.jstor.org/stable/24216527

992

993 Sánchez-Guillén RA, Van Gossum H, Cordero-Rivera A. 2005. Hybridization and the

994 inheritance of female colour polymorphism in two ischnurid damselflies (Odonata:

995 Coenagrionidae). Biological Journal of the Linnean Society 85: 471-481.

996 DOI: $10.1111 / \mathrm{j} .1095-8312.2005 .00506 . \mathrm{x}$

997

998 Sánchez-Guillén RA, Wellenreuther M, Cordero-Rivera A, Hansson B. 2011. Introgression and 999 rapid species turnover in sympatric damselflies. BMC Evolutionary Biology 11: 210.

1000 DOI: $10.1186 / 1471-2148-11-210$

1001

1002

Sánchez-Guillén R, Córdoba-Aguilar A, Cordero-Rivera A, Wellenreuther M. 2014. Genetic

1003 divergence predicts reproductive isolation in damselflies. Journal of Evolutionary Biology 27:

1004 76-87.

1005 DOI: $10.1111 /$ jev.12274

1006

1007

Schlick-Steiner BC, Steiner FM, Seifert B, Stauffer C, Christian E, Crozier RH. 2010. Integrative

1008 taxonomy: A multisource approach to exploring biodiversity. Annual Review of Entomology.

1009 DOI: 10.1146/annurev-ento-112408-085432.

1010

1011

Schmid-Egger C, Straka J, Ljubomirov T, Blagoec GA, Morinière J, Schmidt S. 2019. DNA

1012 barcodes identify 99 per cent of apoid wasp species (Hymenoptera: Ampulicidae, Crabonidae, Sphecidae) from the Western Palearctic. Molecular Ecology Resources 19: 486-484.

1014 DOI: $10.1111 / 1755-0998.12963$

1015

1016 Seidenbusch R. 1996. Die Bedeutung der Memtumgelenkbeulen und des

1017 Memtumborstenwinkels für die Larvaldetermination am Beispiel einiger Coenagrionidae.

1018 Sulzbach-Rosenberger Libellenrundbriefe, Ausgabe III, April.

1019

1020

Simaika JP, Samways MJ. 2009. An easy-to-use index of ecological integrity for prioritizing 1021 freshwater sites and for assessing habitat quality. Biodiversity and Conservation 18: 1171-1185. DOI: $10.1007 / \mathrm{s} 10531-008-9484-3$

1023

1024

1025

Solano E, Hardersen S, Audisio P, Amorosi V, Seczuk G, Antonini G. 2018. Asymmetric

1026 hybridization in Cordulegaster (Odonata: Cordulegastridae): Secondary postglacial contact and the possible role of mechanical constraints. Ecology and Evolution 8: 9657-9671. 
1027

1028

1029

1030

1031

1032

1033

1034

1035

1036

1037

1038

1039

1040

1041

1042

1043

1044

1045

1046

1047

1048

1049

1050

1051

1052

1053

1054

1055

1056

1057

1058

1059

1060

1061

1062

1063

1064

1065

1066

DOI: $10.1002 /$ ece 3.4368

Struck TH, Cerca J. 2020. Cryptic Species and Their Evolutionary Significance. In eLS , John Wiley \& Sons, Ltd (Ed.).

https://DOI: 10.1002/9780470015902.a0028292

Sun Z, Majaneva M, Sokolova E, Rauch S, Meland S, Ekrem T.2019. DNA metabarcoding adds valuable information for management of biodiversity in roadside stormwater ponds. Ecology and Evolution9: 9712-9722.

DOI: $10.1002 /$ ece 3.5503

Taberlet P, Coissac E, Pompanon F, Brochman C, Willerslev E. 2012. Towards next generation biodiversity assessment using DNA metabarcoding. Molecular Ecology 21, 2045-2050.

DOI: $10.1111 / \mathrm{j} .1365-294 X .2012 .05470 . x$.

Thongprem, P., Davison, H. R., Thompson, D. J., Lorenzo-Carballa, M. O., \& Hurst, G. D.

(2020). Incidence and Diversity of Torix Rickettsia-Odonata Symbioses. Microbial Ecology, 110.

DOI: $10.1007 / \mathrm{s} 00248-020-01568-9$

Trebitz AS, Hoffman JC, Grant GW, Billehus TM, Pilgrim EM. 2015. Potential for DNA-based identification of Great Lakes fauna: Match and mismatch between taxa inventories and DNA barcode libraries. Scientific Reports 5:1-11.

DOI: $10.1038 /$ srep 12162 .

Tynkkynen K, Grapputo A, Kotiaho JS, Rantala M, Väänänen S, Suhonen J. 2008. Hybridization in Calopteryx damselflies: the role of males. Animal Behavior 75: 1431-1439.

DOI: 10.1016/j.anbehav.2007.09.017

Valentini A, Pompanon F, Taberlet P. 2008. DNA barcoding for ecologists. Trends in Ecology and Evolution 24: 110-117.

DOI: $10.1016 /$ j.tree.2007.09.011

Vega-Sánchez YM, Mendoza-Cuenca LF, Gonzalez-Rodriguez A 2020. Hetaerina calverti

(Odonata: Zygoptera: Calopterygidae) sp. nov., a new cryptic species of the American Rubyspot complex Zootaxa 4766 (3)

DOI: $10.11646 /$ zootaxa.4766.3.7

Viganò M, Janni O, Corso A. 2017. Tramea basilaris on Linosa Island, Italy: A new species for Europe and the Western Palaearctic (Odonata: Libellulidae). Odonatologica, 46(1/2), 55-66. 
1067

1068

1069

1070

1071

1072

1073

1074

1075

1076

1077

1078

1079

1080

1081

1082

1083

1084

1085

1086

1087

1088

1089

1090

1091

1092

1093

1094

1095

1096

1097

1098

1099

1100

1101

1102

1103

1104

1105

1106

Ward RD, Hanner R, Hebert PDN. 2009. The campaign to DNA barcode all fishes, FISH-BOL. Journal of Fish Biology 74: 329-356.

DOI: $10.1111 / j .1095-8649.2008 .02080 . x$

Weigand H, Beermann AJ, Čiampor F, Costa FO, Csabai Z, Duarte S, Geiger MF, Grabowski M, Rimet F, Rulik B, Strand M, Szucsich N, Weigand AM, Willassen E, Wyler SA, Bouchez A, Borja A, Čiamporová-Zat’ovičová Z, Ferreira S, Dijkstra KDB, Eisendle U, Freyhof J, Gadawski P, Graf W, Haegerbaeumer A, van der Hoorn BB, Japoshvili B, Keresztes L, Keskin E, Leese F, Macher JN, Mamos T, Paz G, Pešić V, Pfannkuchen DM, Pfannkuchen MA, Price BW, Rinkevich B, Teixeira MAL, Várbíró G, Ekrem T. 2019. DNA barcode reference libraries for the monitoring of aquatic biota in Europe: Gap-analysis and recommendations for future work.

Science of the Total Environment 678:499-524.

DOI: 10.1016/j.scitotenv.2019.04.247.

Weekers PHH, De Jonckheere JF, Dumont HJ. 2001. Phylogenetic relationships inferred from ribosomal ITS sequences and biogeographic patterns in representatives of the genus Calopteryx (Insecta: Odonata) of the West Mediterranean and adjacent West European zone. Molecular Phylogenetics and Evolution, 20, 89-99.

DOI: $10.1006 / \mathrm{mpev} .2001 .0947$

Wellenreuther M, Muñoz J, Chávez-Ríos JR, Hansson B, Cordero-Rivera A, Sánchez-Guillén R. 2018. Molecular and ecological signatures of an expanding hybrid zone. Ecology and Evolution 8: 4793-4806.

DOI: $10.1002 /$ ece 3.4024

Zangl L, Daill D, Schweiger S, Gassner G, Koblmüller S. 2020. A reference DNA barcode library for Austrian amphibians and reptiles. PLoS One 15: e0229353.

DOI: 10.1371/journal.pone.0229353

Zettler ML, Proffitt CE, Darr A, Degraer S, Devriese L, Greathead C, Kotta J, Magni P, Martin G, Reiss H, Speybroeck J, Tagliapietra D, Van Hoey G, Ysebaert T. 2013. On the Myths of Indicator Species: Issues and Further Consideration in the Use of Static Concepts for Ecological Applications. PLoS ONE.

DOI: 10.1371/journal.pone.0078219.

Zhang F, Gao F, Jakovlić I, Zou H, Zhang J, Li WX, Wang GT. 2020. PhyloSuite: An integrated and scalable desktop platform for streamlined molecular sequence data management and evolutionary phylogenetic studies. Molecular Ecology Resources 20: 348-355.

DOI: $10.1111 / 1755-0998.13096$

Peer) reviewing PDF | (2020:08:52354:1:1:NEW 11 Feb 2021) 
1107

1108 Zizka VMA, Leese F, Peinert B, Geiger MF. 2019. DNA metabarcoding from sample fixative as 1109 a quick and voucher-preserving biodiversity assessment method. Genome 62:122-136.

1110 DOI: 10.1139/gen-2018-0048.

1111

1112 Zizka VMA, Geiger MF, Leese F. 2020. DNA metabarcoding of stream invertebrates reveals 1113 spatio-temporal variation but consistent status class assessments in a natural and urban river.

1114 Ecological Indicators, 115, 106383.

1115 DOI: 10.1016/j.ecolind.2020.106383 


\section{Figure 1}

Map of the 274 sampling locations for the 663 specimens with GPS coordinates deposited in BOLD and pictures for a representative for each family.

Circle size corresponds to the number of specimens analysed from the respective site.

Pictures show representatives for each family: ANISOPTERA - Libellulidae: Sympetrum sanguineum (A), Corduliidae: Cordulia aenea (B), Libellulidae: Libellula quadrimaculata (C), Aeshnidae: Aeshna subarctica (D), Gomphidae: Gomphus vulgatissimus (E), Cordulegastridae: Cordulegaster boltonii (F). ZYGOPTERA - Coenagrionidae: Erythromma najas (G), Platycnemididae: Platycnemis pennipes (H), Calopterygidae: Calopteryx splendens, female (I), Calopteryx splendens, male (J), Lestidae: Lestes sponsa (K), Coenagrionidae: Coenagrion mercuriale (L). Photos: F. Petzold (F) and S. Koch (all other).

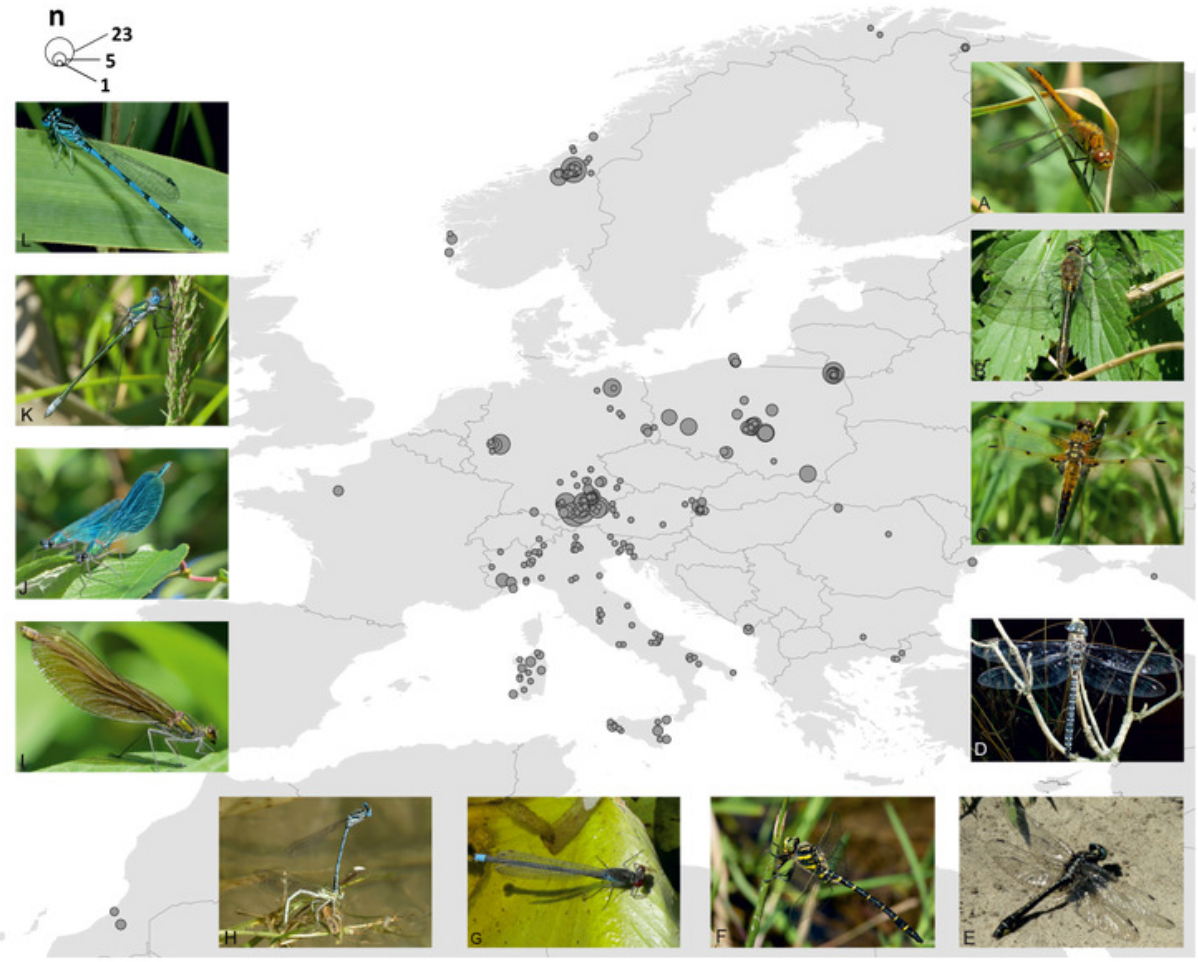


Figure 2

Maximum likelihood estimation of the phylogenetic relationships for Anisoptera (dragonflies) based on the mitochondrial COI DNA barcode region (GTR+F+R5 model with 10000 ultrafast bootstrap replicates). 


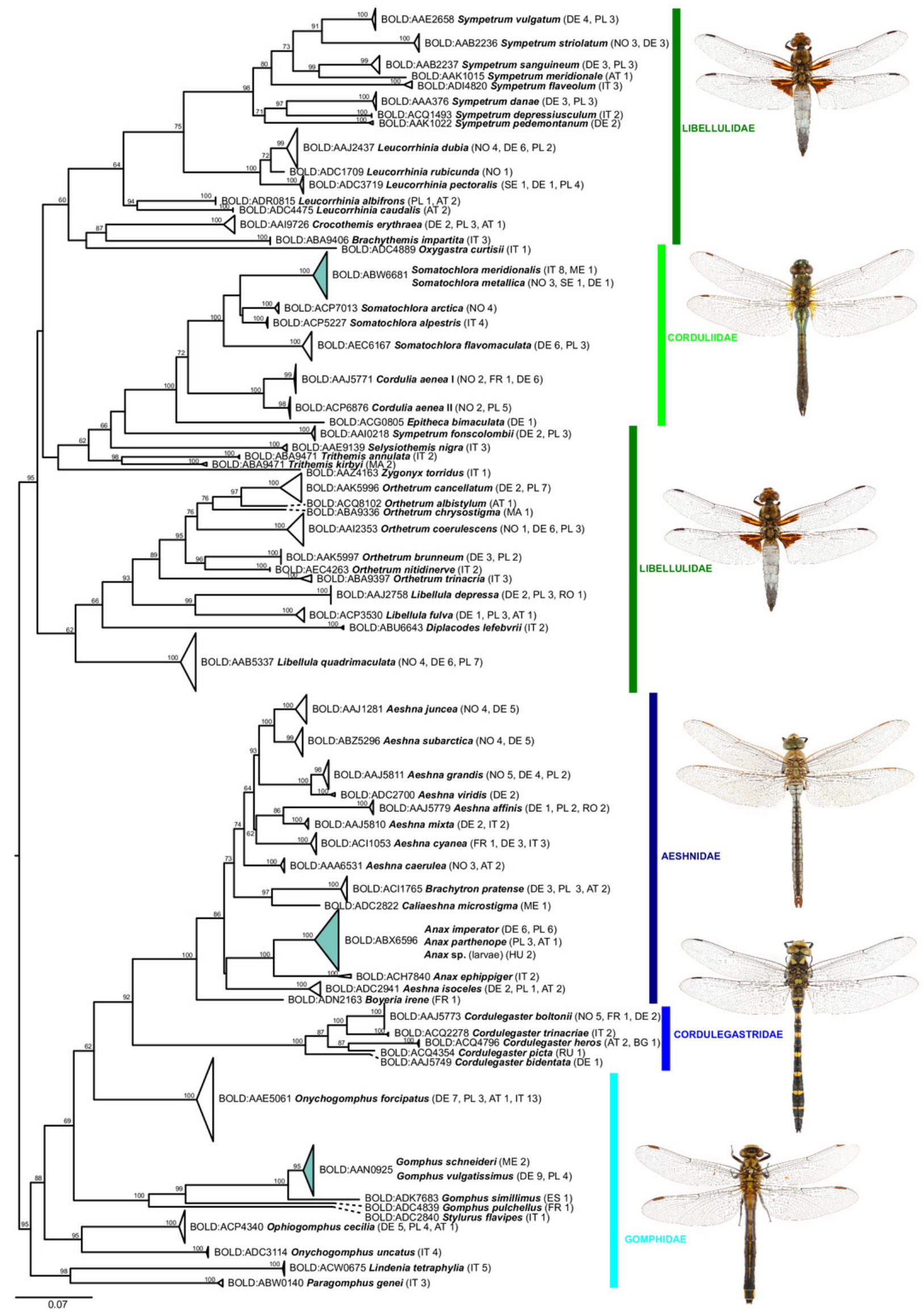


Figure 3

Maximum likelihood estimation of the phylogenetic relationships for Zygoptera (damselflies) based on the mitochondrial COI DNA barcode region (GTR+F+R3 model with 10000 ultrafast bootstrap replicates). 


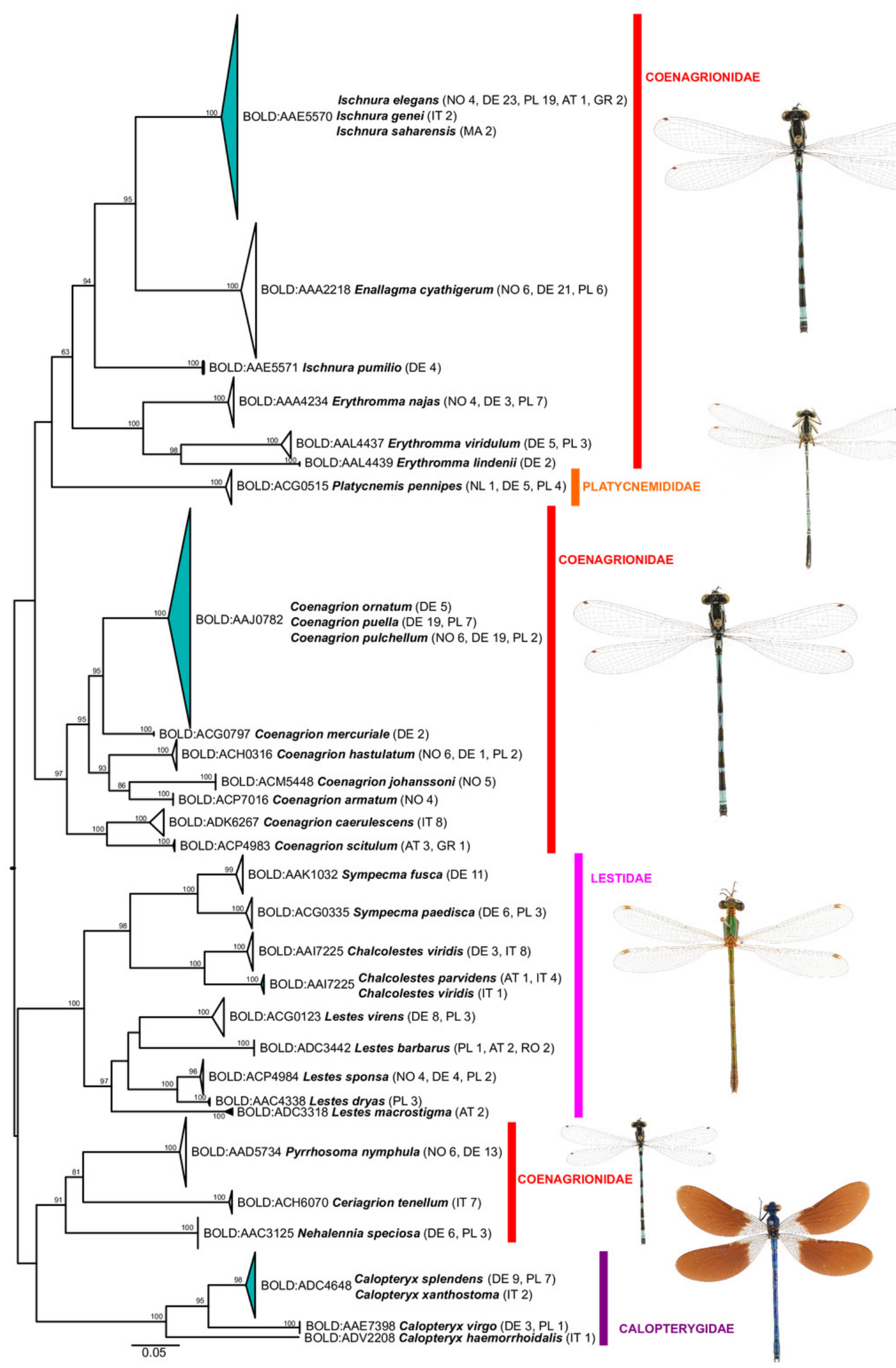

Peer) reviewing PDF | (2020:08:52354:1:1:NEW 11 Feb 2021) 


\section{Figure 4}

Example of the occurrence of BIN sharing due to low but consistent mitochondrial differentiation in Anax imperator and $A$. parthenope.

Public domain illustrations taken from Lucas 1900 (made available from http://www.animalbase.uni-goettingen.de) and the Japanese journal Dobutsugaku zasshi 1901-1903 (made available from the Biodiversity Heritage Library. Contributed by the American Museum of Natural History Library | www.biodiversitylibrary.org). ML-tree inferred with model $\mathrm{HKY}+\mathrm{F}+\mathrm{I}$. 


Figure 5

Example of the occurrence of deep mitochondrial divergence in Cordulia aenea.

Public domain illustration taken from Lucas 1900 (made available from

http://www.animalbase.uni-goettingen.de; male left). ML-tree inferred with model

$\mathrm{TIM} 2+\mathrm{F}+\mathrm{G} 4$. 







\section{Table $\mathbf{1}$ (on next page)}

Result of the internal BIN discordance report (BOLD v4) for the 7 BINs of 183 individuals with conflicting species-level information associated when compared to all data in the dataset DS-ODOGER.

* as of 2020-05-18 in BOLD including all records (public and non-public); additional taxa might be included, which are not listed here 
1

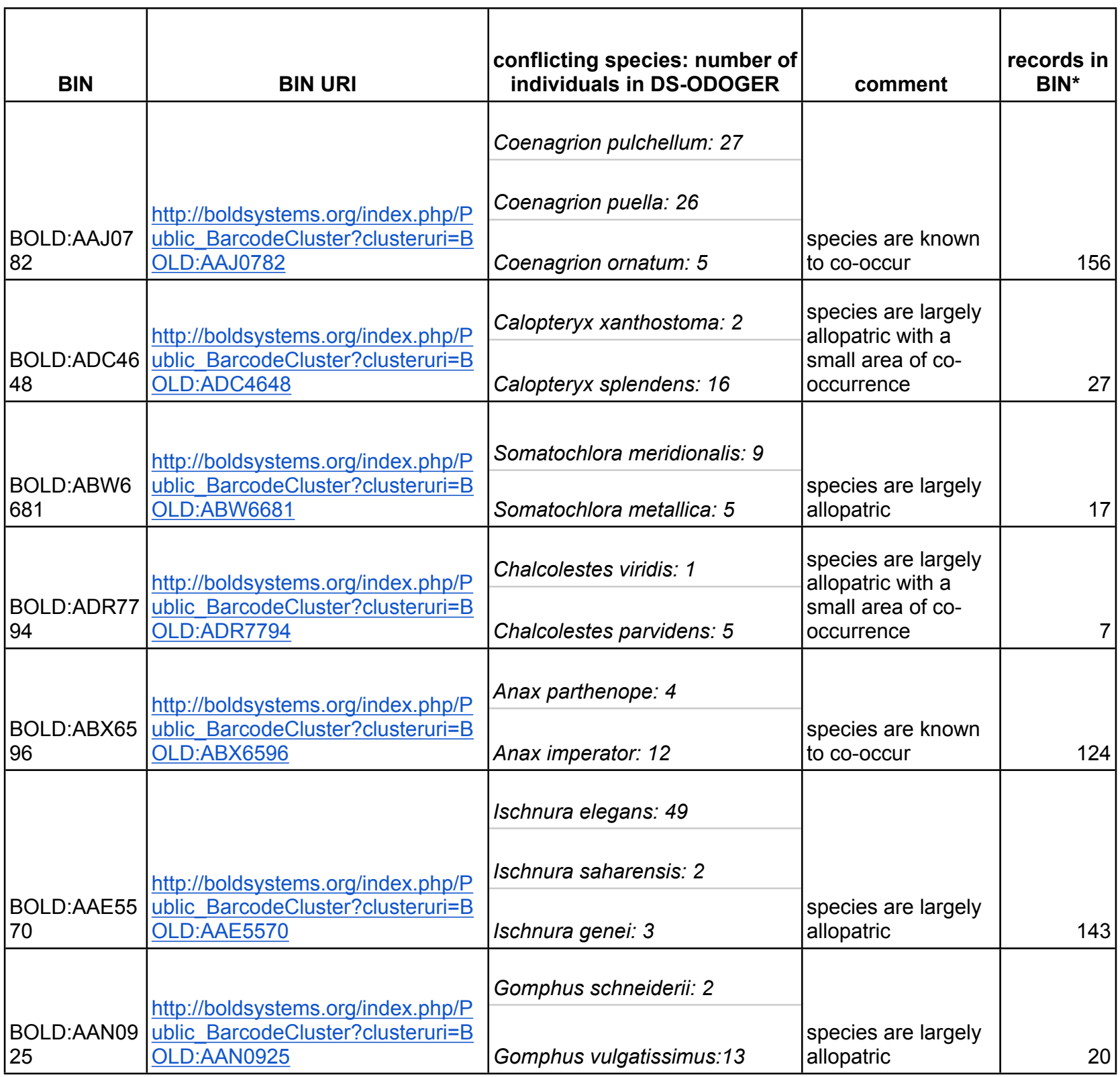

2

3 * as of 2020-05-18 in BOLD including all records (public and non-public); additional taxa might 4 be included, which are not listed here 


\section{Table 2 (on next page)}

Result of the global BIN discordance report (BOLD v3) for the 18 BINs with conflicting species-level information associated when compared to all data in BOLD.

* as of 2020-05-18 in BOLD including all records (public and non-public); ${ }^{2}$ umber of individuals with and without $\mathrm{COI}$ sequences available 


\begin{tabular}{|c|c|c|c|c|}
\hline BIN & BIN URI & $\begin{array}{c}\text { conflicting species: number of individuals in } \\
\text { DS-ODOGER }\end{array}$ & comment & $\begin{array}{l}\text { recor } \\
\text { ds in } \\
\text { BIN* }^{*}\end{array}$ \\
\hline $\begin{array}{l}\text { BOLD:AAA2 } \\
218\end{array}$ & $\begin{array}{l}\text { http://boldsystems.org/index. } \\
\text { php/Public BarcodeCluster? } \\
\text { clusteruri=BOLD:AAA2218 }\end{array}$ & $\begin{array}{l}\text { Enallagma cyathigerum[69], Enallagma } \\
\text { hageni[28], Enallagma boreale[22], Enallagma } \\
\text { annexum[19], Enallagma ebrium[18], Enallagma } \\
\text { divagans[4], Enallagma clausum[3], Enallagma } \\
\text { circulatum[3], Enallagma laterale[2], Enallagma } \\
\text { minusculum[2], Enallagma geminatum[2], } \\
\text { Enallagma carunculatum[2], Enallagma sp. } \\
\text { DNAS-283-223485[1], Enallagma aspersum[1], } \\
\text { Enallagma sp.[1] }\end{array}$ & $\begin{array}{l}\text { E. } \\
\text { cyathigerum } \\
\text { is the only } \\
\text { Enallagma } \\
\text { species with } \\
\text { a Palearctic } \\
\text { distribution, } \\
\text { the other } \\
\text { twelve } \\
\text { species have } \\
\text { been } \\
\text { described } \\
\text { later and are } \\
\text { recorded } \\
\text { from the } \\
\text { Nearctic only. }\end{array}$ & 694 \\
\hline $\begin{array}{l}\text { BOLD:AAA6 } \\
531\end{array}$ & $\begin{array}{l}\text { http://boldsystems.org/index. } \\
\text { php/Public BarcodeCluster? } \\
\text { clusteruri=BOLD:AAA6531 }\end{array}$ & $\begin{array}{l}\text { Aeshna septentrionalis[26], Aeshna caerulea[7], } \\
\text { Aeshna sitchensis[3] }\end{array}$ & & 37 \\
\hline $\begin{array}{l}\text { BOLD:AAB2 } \\
237\end{array}$ & $\begin{array}{l}\text { http://boldsystems.org/index. } \\
\text { php/Public BarcodeCluster? } \\
\text { clusteruri=BOLD:AAB2237 }\end{array}$ & $\begin{array}{l}\text { Sympetrum sanguineum[20], Sympetrum } \\
\text { striolatum[1] }\end{array}$ & $\begin{array}{l}\text { identification } \\
\text { or sequence } \\
\text { submission } \\
\text { error very } \\
\text { likely }\end{array}$ & 20 \\
\hline $\begin{array}{l}\text { BOLD:AAD5 } \\
734\end{array}$ & $\begin{array}{l}\text { http://boldsystems.org/index. } \\
\text { php/Public BarcodeCluster? } \\
\text { clusteruri=BOLD:AAD5734 }\end{array}$ & $\begin{array}{l}\text { Pyrrhosoma nymphula[40], Pyrrhosoma } \\
\text { elisabethae[5] }\end{array}$ & & 45 \\
\hline $\begin{array}{l}\text { BOLD:AAJ5 } \\
773\end{array}$ & $\begin{array}{l}\text { http://boldsystems.org/index. } \\
\text { php/Public BarcodeCluster? } \\
\text { clusteruri=BOLD:AAJ5773 }\end{array}$ & $\begin{array}{l}\text { Cordulegaster boltonii[37], Cordulegaster } \\
\text { trinacriae[2] }\end{array}$ & & 39 \\
\hline $\begin{array}{l}\text { BOLD:AAJ5 } \\
811\end{array}$ & $\begin{array}{l}\text { http://boldsystems.org/index. } \\
\text { php/Public BarcodeCluster? } \\
\text { clusteruri=BOLD:AAJ5811 }\end{array}$ & Aeshna grandis[20], Aeshna juncea[1] & \begin{tabular}{|l|} 
identification \\
or sequence \\
submission \\
error very \\
likely
\end{tabular} & 21 \\
\hline $\begin{array}{l}\text { BOLD:AAK5 } \\
996\end{array}$ & $\begin{array}{l}\text { http://boldsystems.org/index. } \\
\text { php/Public BarcodeCluster? } \\
\text { clusteruri=BOLD:AAK5996 }\end{array}$ & $\begin{array}{l}\text { Orthetrum cancellatum[27], Orthetrum } \\
\text { albistylum[1] }\end{array}$ & $\begin{array}{l}\text { identification } \\
\text { or sequence } \\
\text { submission } \\
\text { error very } \\
\text { likely }\end{array}$ & 26 \\
\hline $\begin{array}{l}\text { BOLD:AAK5 } \\
997\end{array}$ & $\begin{array}{l}\text { http://boldsystems.org/index. } \\
\text { php/Public BarcodeCluster? } \\
\text { clusteruri=BOLD:AAK5997 }\end{array}$ & $\begin{array}{l}\text { Orthetrum brunneum[19], Orthetrum } \\
\text { lineostigma[2], Orthetrum anceps[1] }\end{array}$ & $\begin{array}{l}\text { identification } \\
\text { or sequence } \\
\text { submission } \\
\text { error very } \\
\text { likely }\end{array}$ & 21 \\
\hline $\begin{array}{l}\text { BOLD:ABA9 } \\
336\end{array}$ & $\begin{array}{l}\text { http://boldsystems.org/index. } \\
\text { php/Public BarcodeCluster? } \\
\text { clusteruri=BOLD:ABA9336 }\end{array}$ & $\begin{array}{l}\text { Orthetrum chrysostigma[24], Orthetrum julia[1], } \\
\text { Orthetrum brachiale[1] }\end{array}$ & & 28 \\
\hline $\begin{array}{l}\text { BOLD:ABA9 } \\
406\end{array}$ & $\begin{array}{l}\text { http://boldsystems.org/index. } \\
\text { php/Public BarcodeCluster? } \\
\text { clusteruri=BOLD:ABA9406 }\end{array}$ & $\begin{array}{l}\text { Brachythemis leucosticta[31], Brachythemis } \\
\text { impartita[8] }\end{array}$ & & 40 \\
\hline $\begin{array}{l}\text { BOLD:ABW0 } \\
140\end{array}$ & $\begin{array}{l}\text { http://boldsystems.org/index. } \\
\text { php/Public BarcodeCluster? }\end{array}$ & Paragomphus genei[20], Paragomphus elpidius[1] & & 23 \\
\hline
\end{tabular}




\begin{tabular}{|c|c|c|c|c|}
\hline & clusteruri=BOLD:ABW0140 & & & \\
\hline $\begin{array}{l}\text { BOLD:ACG0 } \\
515\end{array}$ & $\begin{array}{l}\text { http://boldsystems.org/index. } \\
\text { php/Public BarcodeCluster? } \\
\text { clusteruri=BOLD:ACG0515 }\end{array}$ & Platycnemis pennipes[26], Platycnemis latipes[2] ${ }^{3}$ & $\begin{array}{l}\text { identification } \\
\text { or sequence } \\
\text { submission } \\
\text { error very } \\
\text { likely }\end{array}$ & 28 \\
\hline $\begin{array}{l}\text { BOLD:ACI10 } \\
53\end{array}$ & $\begin{array}{l}\text { http://boldsystems.org/index. } \\
\text { php/Public BarcodeCluster? } \\
\text { clusteruri=BOLD:ACl1053 }\end{array}$ & Aeshna cyanea[25], Aeshna grandis[1] & & 29 \\
\hline $\begin{array}{l}\text { BOLD:ACP4 } \\
984\end{array}$ & $\begin{array}{l}\text { http://boldsystems.org/index. } \\
\text { php/Public BarcodeCluster? } \\
\text { clusteruri=BOLD:ACP4984 }\end{array}$ & Lestes sponsa[25], Lestes sp.[1] & & 18 \\
\hline $\begin{array}{l}\text { BOLD:ACQ1 } \\
493\end{array}$ & $\begin{array}{l}\text { http://boldsystems.org/index. } \\
\text { php/Public BarcodeCluster? } \\
\text { clusteruri=BOLD:ACQ1493 }\end{array}$ & $\begin{array}{l}\text { Sympetrum depressiusculum[22], Sympetrum } \\
\text { frequens[10] }\end{array}$ & & 3 \\
\hline $\begin{array}{l}\text { BOLD:ACQ2 } \\
278\end{array}$ & $\begin{array}{l}\text { http://boldsystems.org/index. } \\
\text { php/Public BarcodeCluster? } \\
\text { clusteruri=BOLD:ACQ2278 }\end{array}$ & $\begin{array}{l}\text { Cordulegaster trinacriae[14], Cordulegaster } \\
\text { boltonii[2] }\end{array}$ & & 16 \\
\hline $\begin{array}{l}\text { BOLD:ACQ4 } \\
354\end{array}$ & $\begin{array}{l}\text { http://boldsystems.org/index. } \\
\text { php/Public BarcodeCluster? } \\
\text { clusteruri=BOLD:ACQ4354 }\end{array}$ & Cordulegaster picta[2], Cordulegaster insignis[1] & & 1 \\
\hline $\begin{array}{l}\text { BOLD:ADC1 } \\
709\end{array}$ & $\begin{array}{l}\text { http://boldsystems.org/index. } \\
\text { php/Public BarcodeCluster? } \\
\text { clusteruri=BOLD:ADC1709 }\end{array}$ & $\begin{array}{l}\text { Leucorrhinia rubicunda[5], Leucorrhinia } \\
\text { intermedia[1] }\end{array}$ & & 5 \\
\hline
\end{tabular}

$\frac{1}{2}$ sequences available 